\title{
Bismuth tellurides and sulphosalts from the Larga hydrothermal system, Metaliferi Mts., Romania: Paragenesis and genetic significance
}

\author{
N. J. CoOK* AND C. L. Ciobanu \\ Geological Survey of Norway, N-7491 Trondheim, Norway
}

\section{ABSTRACT}

Intermediate levels of the Larga-Faţa Băii field, Metaliferi Mts., Romania, are host to epithermal vein mineralization, small skarn-like bodies and 'geode'-like replacement ores, that together form a complex hydrothermal system rooted in the subjacent andesite stock. Silver-Pb-Bi sulphosalts, some with $\mathrm{Sb}$ and/or Se, are intimately associated with hessite and a range of Bi-tellurides with $\mathrm{Bi} /(\mathrm{Te}+\mathrm{S}+\mathrm{Se}) \leqslant 1$ (tetradymite, tellurobismuthite, tsumoite, $\mathrm{Pb}$-free rucklidgeite) within all these ore types. Lillianite homologues, both ordered ${ }^{4} \mathrm{~L}$ and ${ }^{7} \mathrm{~L}$ derivatives (lillianite, gustavite), and disordered varieties are the most abundant sulphosalts, with subordinate bismuthinite derivatives (aikinite, krupkaite, bismuthinite). An exceptionally Ag-rich lillianite homologue, intimately intergrown with tetradymite and hessite, is identified as treasureite on the basis of chemical composition. Porphyry-style mineralization from $600 \mathrm{~m}$ beneath the studied level contains rucklidgeite as the single stable Bi-telluride. The trace mineralogy of the system is suggestive of a hydrothermal system strongly zoned with respect to $f_{\mathrm{Te}_{2}}$ and, to a lesser extent, also $f_{\mathrm{S}_{2}}$. Mineralogical and textural evidence suggests that initial crystallization took place at temperatures in excess of $400^{\circ} \mathrm{C}$. The association of gold with Bi-minerals is linked to the role of $\mathrm{Bi}_{\text {melt }}$ as a scavenger for gold, and deposition within 'droplets' simultaneous with the formation of arsenopyrite from löllingite + pyrrhotite. Both Bi-tellurosulphides and sulphosalts are commonly non-stoichiometric, a fact that can be correlated with order-disorder in both series. When widely distributed, as in the Larga system, trace amounts of Bi-minerals (sulphosalts, tellurides/ tellurosulphides) have considerable, untapped potential as tracers of the physical-chemical character of an evolving hydrothermal system.

KeYwoRDs: tellurides, Bi-sulphosalts, compositional data, Larga, Metaliferi Mts., Romania.

\section{Introduction}

THE Neogene gold deposits of the Metaliferi Mts., Romania (part of the South Apuseni Mountains, Fig. 1a), are considered classic examples of zoned, epithermal $\mathrm{Cu}-\mathrm{Zn}-\mathrm{Pb}-\mathrm{Au}$ porphyry-vein systems (e.g. Ghiţulescu and Socolescu 1941; Ianovici et al., 1969; Berbeleac, 1986; Alderton and Fallick, 2000). The region represents the type locality for a number of Te-bearing minerals

* E-mail: Nigel.Cook@ngu.no

DOI: $10.1180 / 0026461046820188$ (native tellurium, tellurite, krennerite, nagyágite, petzite, sylvanite, muthmannite and stützite). The widespread distribution of Au- and Ag-tellurides is typical for the upper levels of many deposits, from which most historical production (from the Roman era to the 1940s) took place. Modern systematic microanalytical investigations of the mineralogy of the deposits or the hydrothermal systems in their totality are, however, relatively few, chiefly since the telluride-rich segments of many deposits (e.g. Săcărîmb, Bradişor, Musariu (Brad District) and Stănija) are entirely worked out. The occurrence and composition of tellurides has nevertheless been documented from several deposits, and in recent years, also confirmed by 

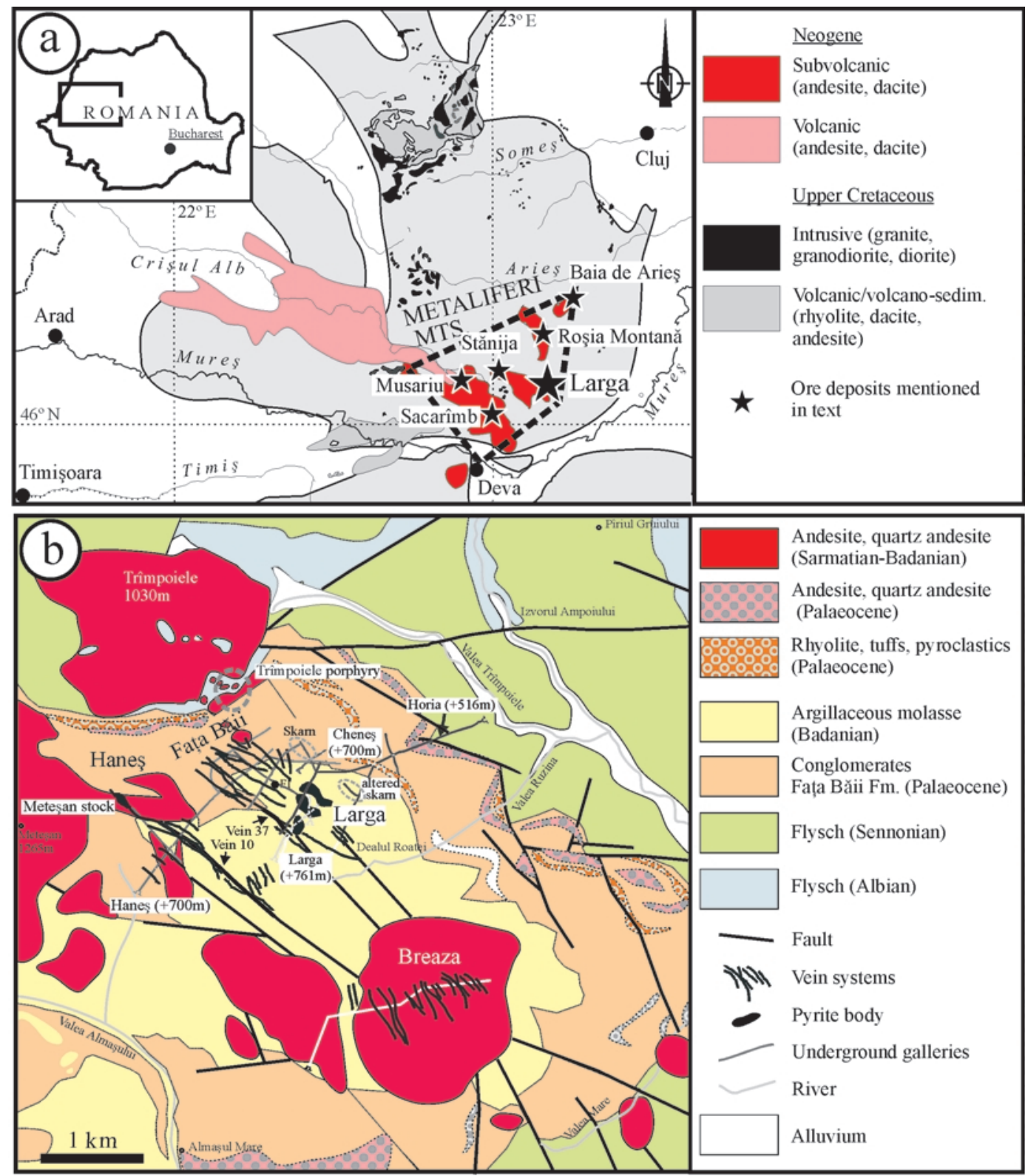

FIG. 1. (a) Geological sketch map of the Metaliferi Mts., showing the principal ore zones, including the ZlatnaStănija volcanic zone that hosts the Faţa Băii-Haneş-Breaza-Larga-Trîmpoiele orefield. The dashed line shows the perimeter of the 'golden quadrangle'. (b) Geological-metallogenetic map of part of the Zlatna-Stănija volcanic zone, indicating the location of ores and underground galleries referred to in the text (projected to surface). Redrawn and modified after Borcoş et al. (1989).

microanalysis (e.g. Koch and Krasselly, 1950; Ramdohr and Udubaşa, 1973; Berbeleac and David, 1982; Popescu and Constantinescu, 1992; Popescu and Şimon, 1992; 1995; Cioflica et al.,
1993; Ioan et al., 1993; Şimon et al., 1994, 1995; Stanley et al., 1994; Şimon and Alderton 1995a,b; Lupulescu (1997); Effenberger et al., 1999; Shimizu et al., 1999). Despite this, the occur- 
rence, paragenetic position and genetic significance of tellurides and other trace minerals in deposits of the Metaliferi Mts. remains insufficiently understood, even though 'tetradymite' is sporadically reported as a trace mineral in the ores on the basis of optical identification (e.g. Ianovici et al., 1969). There are no published accounts of bismuth sulphosalts as trace constituents in the ores, and even the widespread Sb-sulphosalt parageneses in several deposits in the region (e.g. Baia de Arieş; Cioflica et al., 1999) are poorly constrained, due to lack of confirmation of optical mineral identification by microanalysis.

In this contribution, we focus on the occurrence of the abundant Bi-tellurides and sulphosalts within the zoned epithermal system from the Faţa Băii-Haneş-Breaza-Larga-Trîmpoiele district at the southeastern margin of the Metaliferi Mts. (Fig. 1a), their paragenetic relationships, and the genetic significance of these assemblages as indicators of ore formation conditions.

\section{Geological setting}

Larga, together with Faţa Băii, Haneş, Breaza and Trîmpoiele, constitutes a $10 \mathrm{~km}$ wide orefield (Fig. 1b) at the SE end of the Zlatna-Stănija volcanic alignment (Ghiţulescu and Socolescu 1941; Borcoş et al., 1964, 1983). Calc-alkaline volcanic rocks of mid-Miocene age (main stage at 13.5-12.5 Ma; see summary in Roşu, 2001) and associated volcanoclastics form a series of volcanic centres within Cretaceous flysch deposited onto a Jurassic ophiolitic basement. Both the ophiolite sequence and overlying flysch sediments have been emplaced tectonically as a nappe suite during Mid- and Late-Cretaceous events. Ores of the Zlatna area follow the style typical for the region, with initial porphyry copper roots, superimposed by polymetallic vein mineralization at higher levels (Borcoş, 1994; Berbeleac et al., 1995). However, the Larga orefield itself has been modelled (Drew and Berger, 2001) in terms of a sudden vein opening above the porphyry root of the hydrothermal system. In parts, the vein systems are enriched in gold and or silver $(1-5 \mathrm{~g} / \mathrm{t})$, but few reliable published grade data exist. Similarly, metal zonation patterns are not fully clear, although zinc and lead tend to increase with depth. There is also some evidence to show increasing $\mathrm{Au}$ with depth (e.g. Ianovici et al., 1969, p. 645). The original Larga deposit, exploited from access gallery $+761 \mathrm{~m}$ (Fig. 1b), was unique for the Metaliferi Mts., in that early $20^{\text {th }}$ century exploitation concentrated on three lenses of high-grade gold-pyrite ore at the contact of Palaeocene Faţa Băii conglomerate and Badenian shale. More recently, including during the current (re-)exploration of the area (http:// www.egoldfields.com), the 'Larga' deposit has come to mean a series of narrow quartz veins carrying $\mathrm{Cu}, \mathrm{Zn}, \mathrm{Pb}, \mathrm{Ag}$, and $\sim 1-3 \mathrm{~g} / \mathrm{t} \mathrm{Au}$ that extend over a vertical extent of $>500 \mathrm{~m}$ below the pyrite lenses. The largest of these, 'vein 37', has been partially exploited from the adjacent Haneş mine.

We have investigated mineralization in an area of $\sim 1 \mathrm{~km}^{2}$, accessible from the Horia exploration gallery $(+516 \mathrm{~m}), 250 \mathrm{~m}$ below the exploited pyrite ores at Larga and the adjacent Faţa Băii and Haneş vein systems. Mineralization on the + $516 \mathrm{~m}$ level, thus represents an intermediate level in a strongly zoned epithermal system $(\mathrm{Cu}, \mathrm{Zn}-\mathrm{Pb}$ and $\mathrm{Au}$, from bottom to top). Pyrite-arsenopyritegold vein mineralization found in the Horia gallery is positioned between the massive pyrite lenses at Larga sensu stricto and the Au-telluriderich veins of the Faţa Băii deposit, some 250-300 m vertically above the Horia level, and the Trîmpoiele $\mathrm{Cu}-\mathrm{Au}$ prospect, intersected by deep drilling at depths of $500-700 \mathrm{~m}$ beneath the Larga level.

Although the ores are variously $\mathrm{Cu}, \mathrm{Zn}$ or $\mathrm{Pb}$ rich, sometimes only consisting of pyrite, the diverse trace mineralogy and enrichment in tellurides is maintained throughout the entire $1.5 \mathrm{~km}$ vertical extent of the hydrothermal system. Elsewhere (Cook et al., 2001; Cook and Ciobanu, 2002), we have documented the trend from $\mathrm{Au}$-dominant telluride mineralogy (calaverite, sylvanite, with native tellurium and tellurite) at upper levels, to a dominance of $\mathrm{Bi}$ tellurides and -tellurosulphides at depth.

On the Horia gallery (Fig. 2), we distinguish the following distinct types of mineralization: (1) a NW-SE, interrupted strike of veins across a horizontal distance of 800 m, hosted in Faţa Băii conglomerate. At the northwestern end (Cloşca gallery), directly underlying Faţa Băii, veins are Au-rich, pyrite-dominated, clustering around small andesite intrusions and include a $50 \mathrm{~m}$ diameter $\mathrm{Cu}$-stockwork body. Abundant pyrrhotite relics and replacement of pyrrhotite by pyrite ( \pm marcasite) at the hand-specimen scale, indicate pyrrhotite was the initial Fe-sulphide. At the southern termination of the Horia gallery, Vein 37 (at $625 \mathrm{~m}$ on 0 Vest gallery) is the longest (200 $\mathrm{m})$ of several steeply dipping veins and lies 


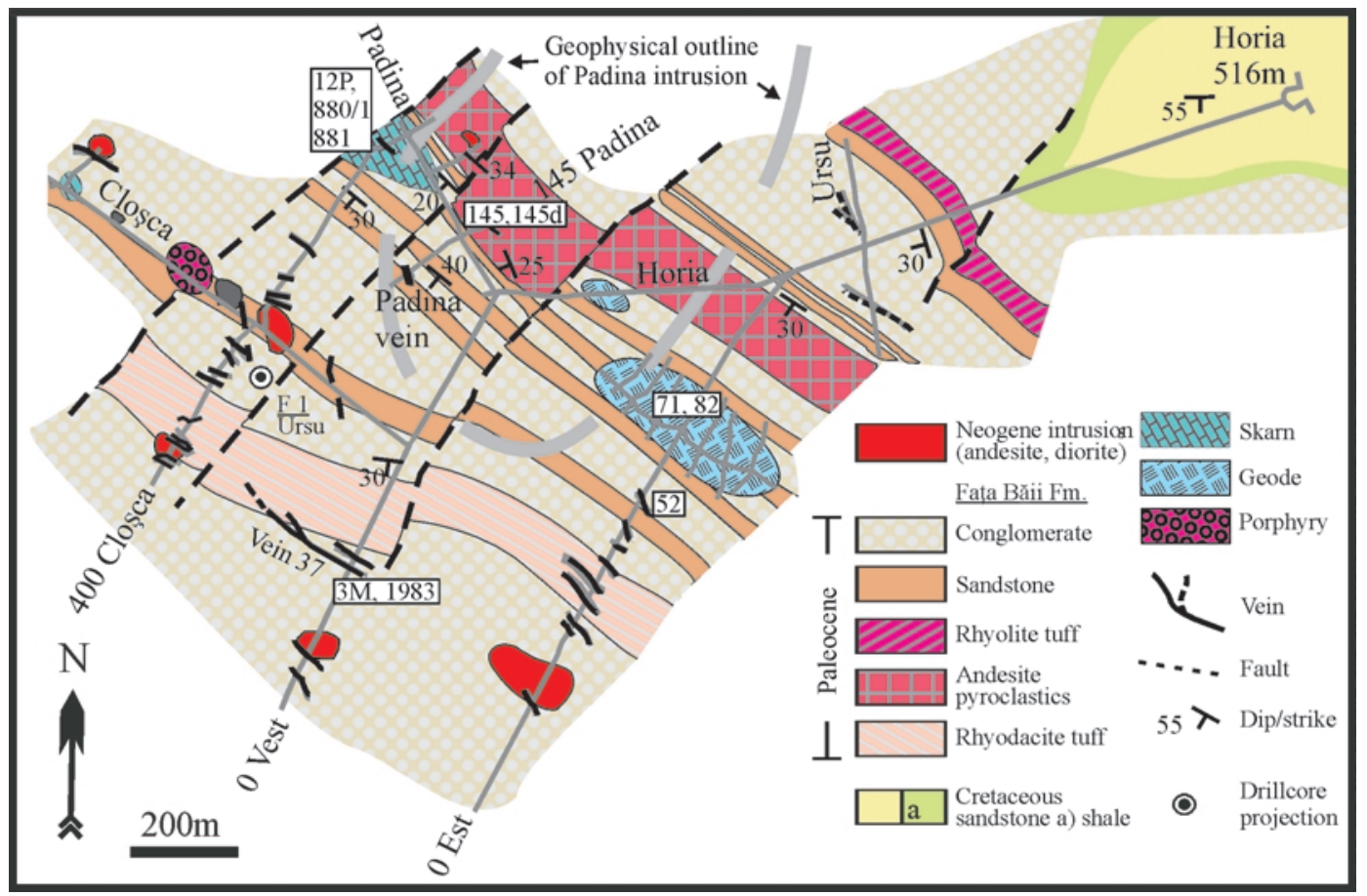

FIG. 2. Geological sketch map of the Horia Gallery and other underground workings accessed from the $+516 \mathrm{~m}$ level (plan view). The detail is essentially based on mapping carried out by one of the present authors (CLC; Intreprinderea de Prospecţiuni Geologice şi Geofizice, Bucharest, unpubl. rep., 1991). The numbers in boxes are the locations of specific samples mentioned in the text and figures.

directly beneath the pyrite lenses (Figs 1 and 2). (2) A parallel strike of altered $\mathrm{Zn}-\mathrm{Pb}$ skarn, some $400 \mathrm{~m}$ to northeast of the veins, relating to a limestone marker horizon in the conglomerate. These in turn can be sub-divided into a single lenticular body of mineralized boulders and 'geode'-style mineralization within advanced argillic alteration conglomerate, $500 \times 150 \mathrm{~m}$ in dimensions on 0 Est gallery, and secondly, a body of garnet-epidote skarn hosting $\mathrm{Zn}-\mathrm{Pb}-(\mathrm{Cu})$ mineralization (Padina gallery).

$500 \mathrm{~m}$ further northwest, along the strike of the skarn, porphyry $\mathrm{Cu}-\mathrm{Au}$ mineralization, as fine veinlets in altered andesite, is intersected in drillcore at the margin of the Trîmpoiele andesite at a depth of $950-1000 \mathrm{~m}$ from surface. A second, smaller porphyry body is exposed on Cloşca gallery and has been followed down to $1000 \mathrm{~m}$ from surface (Ursu F-1 drillhole; Fig. 2). Our investigations show that the Te-rich character of the system clearly persists to this depth, but that Au-tellurides are absent in this porphyry mineralization.

\section{Mineralogy}

The mineral assemblage common to Vein 37, as seen in 0 Vest, and in the group of veins in 0 Est (Fig. 2) is arsenopyrite, pyrite, galena, sphalerite, chalcopyrite, marcasite, relict löllingite, pyrrhotite and gold $\left(\mathrm{Au}_{90-96} \mathrm{Ag}_{4-10}\right)$. Particularly in 0 Est, a brecciated carbonate ( \pm quartz-clay mineral-chlorite) gangue hosts the sulphide ore. The As-rich character does not extend to the veins in Cloşca immediately subjacent to the Faţa Băii veins.

In the veins on 0 Vest and 0 Est galleries, gold occurs chiefly at grain boundaries within arsenopyrite containing löllingite relics (Fig. $3 a$ ). Arsenopyrite displays prominent compositional zonation, with $\mathrm{Sb}$ contents of up to $5 \mathrm{wt} . \%$. In veins exposed on the $+516 \mathrm{~m}$ gallery, Bi-tellurides/tellurosulphides are associated with hessite and galena (Fig. $3 b$ and $c$ ). These are typical as composite inclusions in arsenopyrite, pyrite, sphalerite and more rarely galena, and an association with gold is common. They are 

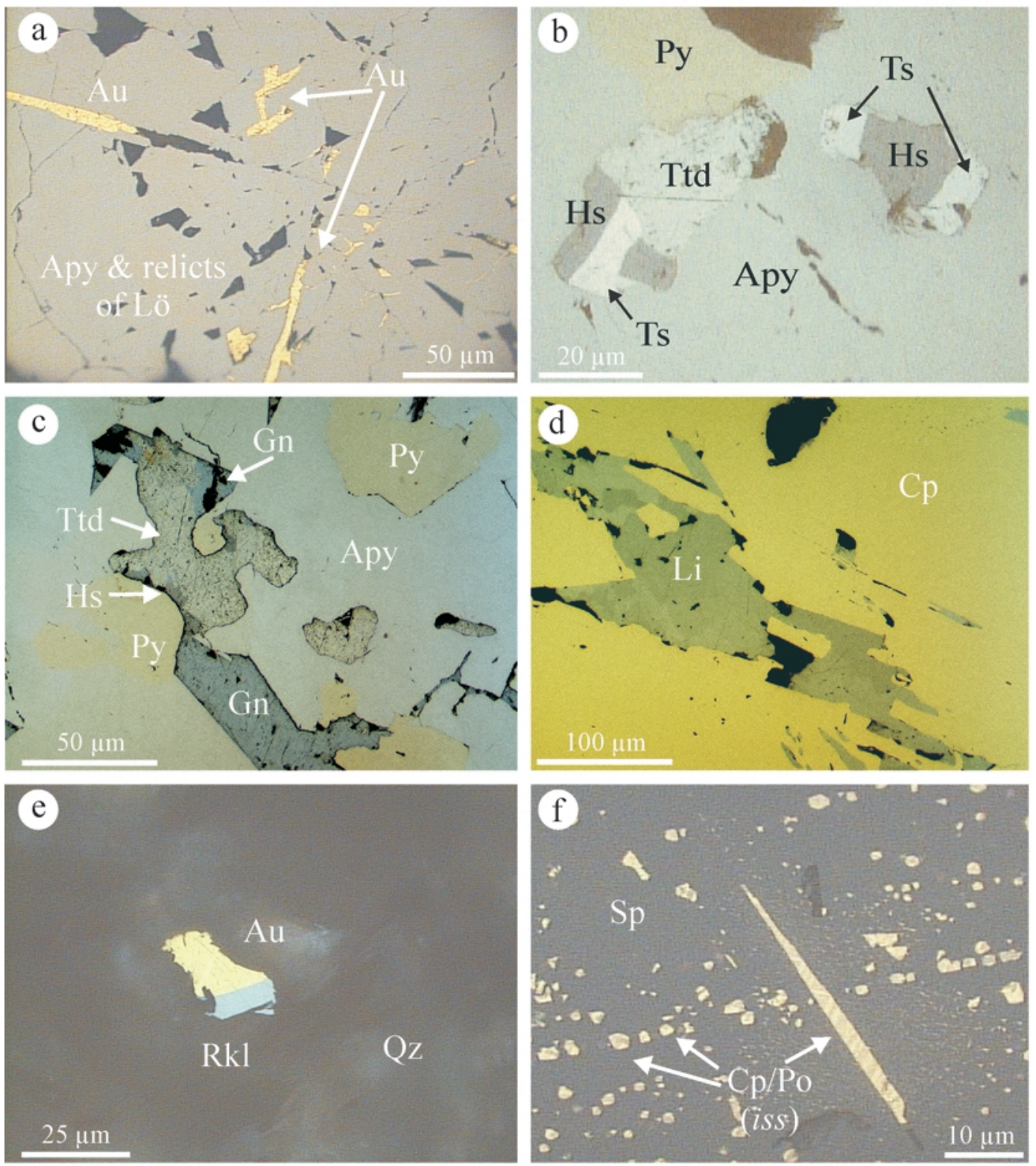

Fig. 3. Photomicrographs in reflected light showing paragenetic relationships of ore minerals in Larga ores. (a) Inclusions of gold (Au) within an intergrowth of arsenopyrite (Apy) and relict löllingite (Lo). Sample: 52 (0 Est gallery). (b) Association of tellurides in pyrite (Py) and arsenopyrite (Apy) within typical vein mineralization. Ttd: tetradymite, Hs: hessite, Ts: tsumoite. Sample: 3M (Vein 37 at 625 m, 0 Vest gallery). (c) Inclusions of tetradymite (Ttd) within a matrix of arsenopyrite (Apy) and pyrite (Py). Note the co-existence of hessite (Hs) and galena (Gn). Sample: 3M (Vein 37 at $625 \mathrm{~m}, 0$ Vest gallery). (d) Typical occurrence of bismuth sulphosalts, in this case dominantly composed of Sb-bearing lillianite (Li) as inclusions in chalcopyrite (Cp). Sample: 145 (vein in Padina gallery). (e) Association of gold (Au) and rucklidgeite (Rkl) in quartz within the Trimpoiele porphyry deposit. Sample: T960. ( $f$ ) Inclusions of chalcopyrite and pyrrhotite crystallized from intermediate solid solution $(\mathrm{Cp} / \mathrm{Po})$ within Haneş veins dominated by sphalerite (Sp). Sample: 1963. 
markedly less common in the Cloşca veins, which instead contain $\mathrm{Pb}-\mathrm{Sb}$ sulphosalts. Bismuth sulphosalts occur sporadically within the veins, in some cases, particularly within the Padina vein, becoming a major component ( $>1 \mathrm{vol} . \%)$ of the galena-pyrite ores (Fig. 3d). Cervelleite, $(\mathrm{Ag}, \mathrm{Cu})_{4} \mathrm{TeS}$, is a minor accessory; its association with hessite, galena and arsenopyrite, and its chemistry have been described elsewhere (Cook and Ciobanu, 2003). Other trace minerals include secondary acanthite and two members of the canfieldite-argyrodite series, $\mathrm{Ag}_{8} \mathrm{SnS}_{6}$ and $\left(\mathrm{Ag}_{7.39} \mathrm{Cu}_{0.73} \mathrm{Fe}_{0.29}\right)_{8.41} \mathrm{Ge}_{0.77} \mathrm{~S}_{5.82}$.

The skarn ore comprises sphalerite (8-9 wt.\% $\mathrm{Fe}$ ), seleniferous galena (up to 7.3 wt.\% $\mathrm{Se}$ ), pyrite, arsenopyrite, with accessory stannite and zoned tetrahedrite-tennantite with typical compositions in the range $\mathrm{Cu}_{10}\left(\mathrm{Fe}_{0.2-0.3} \mathrm{Zn}_{1.7-1.8}\right)_{2}$ $\left(\mathrm{As}_{1.6-2.5} \mathrm{Sb}_{1.5-2.4}\right)_{4} \mathrm{~S}_{13}$. Bismuth tellurides and tellurosulphides occur at sphalerite- and pyritegangue boundaries or enclosed within sphalerite. Assemblages are tellurobismuthite + tetradymite; more rarely tellurobismuthite $+\mathrm{Pb}$-free rucklidgeite, with $\mu \mathrm{m}$-scale inclusions of galena abundant in tellurobismuthite. The pyrrhotite is largely replaced by pyrite and/or marcasite. In both styles of mineralization, hessite and altaite are persistent accessories. Sylvanite and petzitegold-hessite decomposition products of sylvanite are both identified in minor quantities.

The aforementioned porphyry style mineralization in Trimpoiele is dominated by quartz veinlets within altered andesite and biotite hornfels, and carry sporadic pyrrhotite (both hexagonal and monoclinic), chalcopyrite, seleniferous galena and molybdenite; pyrite is abundant in the upper half of the stock. Gold is abundant within the sections we have investigated, as is a close association with the sole Bi-telluride, rucklidgeite (Fig. 3e). Accessories include altaite, clausthalite and bismuthinite.

We have also examined veins in the Haneş mine from a level $\sim 100 \mathrm{~m}$ lower than the Horia gallery. These veins are sphalerite-dominant, with accessory stannite. Within $\mu \mathrm{m}$-scale inclusions in sphalerite and pyrite, there is abundant evidence for initial intermediate solid solution (iss), from which chalcopyrite and pyrrhotite exsolved (Fig. 3f).

\section{Microanalysis}

EPMA was carried out using the JEOL JXA 8600 instruments at Bristol University and the Natural
History Museum, London (both UK). Operating conditions were $20 \mathrm{nA} / 15 \mathrm{kV}$ in both cases. Standards and radiations used were as follows: $\mathrm{Bi}_{2} \mathrm{~S}_{3}(\mathrm{Bi}-M \alpha)$, $\mathrm{PbS}(\mathrm{Pb}-L \alpha / M \alpha, \mathrm{S}-K \alpha), \mathrm{FeS}_{2}$ $(\mathrm{Fe}-K \alpha, \mathrm{S}-K \alpha), \mathrm{CuFeS}_{2}(\mathrm{Cu}-K \alpha), \mathrm{ZnS}(\mathrm{Zn}-K \alpha)$, $\mathrm{Bi}_{2} \mathrm{Te}_{3}(\mathrm{Te}-L \alpha), \mathrm{Bi}_{2} \mathrm{Se}_{3}(\mathrm{Se}-L \alpha)$, Ag metal $(L \alpha)$, $\mathrm{CdS}(\mathrm{Cd}-L \alpha)$ and $\mathrm{Sb}_{2} \mathrm{~S}_{3}(\mathrm{Sb}-L \alpha)$. Overlap and matrix corrections were carried out following established practices and software in the two laboratories. We have analysed the same and similar material from Larga in other laboratories. e.g. Adelaide, Australia and Salzburg, Austria ${ }^{1}$, at a variety of operating conditions, and are satisfied that the data set is not affected by systematic errors beyond normal instrumental precision.

\section{Bi-tellurides/tellurosulphides}

\section{Mineralogy}

In Vein 37 (0 Vest gallery), tetradymite and tsumoite are abundant as $20-100 \mu \mathrm{m}$ inclusions in arsenopyrite, associated with galena and hessite. The morphology of the composite inclusions (Fig. 4a) indicates crystallization from a melt under equilibrium conditions. Minor quantities of $\mathrm{Bi}_{3} \mathrm{Te}_{4}$, a virtually $\mathrm{Pb}$-free rucklidgeite, are noted at the boundaries of tetradymite. Although $\mathrm{Au}-$ tellurides are scarce in veins from the intermediate levels, they are nevertheless present as sylvanite (and breakdown products thereof), native tellurium, tellurobismuthite and hessite (Fig. 4b). The skarn ores contain the persistent assemblage tetradymite + tellurobismuthite + altaite, within calcite gangue, forming a rim on pyrite, or enclosed in galena, and rarely pyrite (Fig. $4 c-f$ ). Both tetradymite (Fig. 4e) and tellurobismuthite persistently contain sub-5 $\mu \mathrm{m}$ inclusions of galena, and more rarely, altaite. Pb-bearing rucklidgeite, $(\mathrm{PbBi})_{3} \mathrm{Te}_{4}$, is the sole Bi-telluride observed in the Trîmpoiele porphyry. The 'geode' ores contain abundant tellurides as inclusions in sphalerite and pyrite (Fig. 5a). These are typically composite and consist of hessite, tetradymite, altaite and volynskite (Fig. $5 b$ and $c$ ), but also contain relatively large amounts of a conspicuous intergrowth of decomposition products of a AuAg-Te-S phase (Fig. $5 d$ ).

${ }^{1}$ The analyses of a pavonite homologue (Table 3) were obtained in Salzburg: JEOL JXL-8600; $25 \mathrm{kV}, 35 \mathrm{na}, \mathrm{S}$ $K \alpha\left(\mathrm{Bi}_{2} \mathrm{~S}_{3}\right), \mathrm{Ag} L \alpha(\mathrm{Ag}), \mathrm{Sb} L \alpha\left(\mathrm{Sb}_{2} \mathrm{~S}_{3}\right), \mathrm{Cd} L \alpha(\mathrm{CdTe})$, Te $L \alpha(\mathrm{CdTe})$, Se $K \alpha\left(\mathrm{Bi}_{2} \mathrm{Se}_{3}\right)$, Bi $L \alpha\left(\mathrm{Bi}_{2} \mathrm{~S}_{3}\right), \mathrm{Pb} L \alpha$ (PbS), $\mathrm{Cu} \mathrm{K \alpha}\left(\mathrm{CuFeS}_{2}\right)$. 

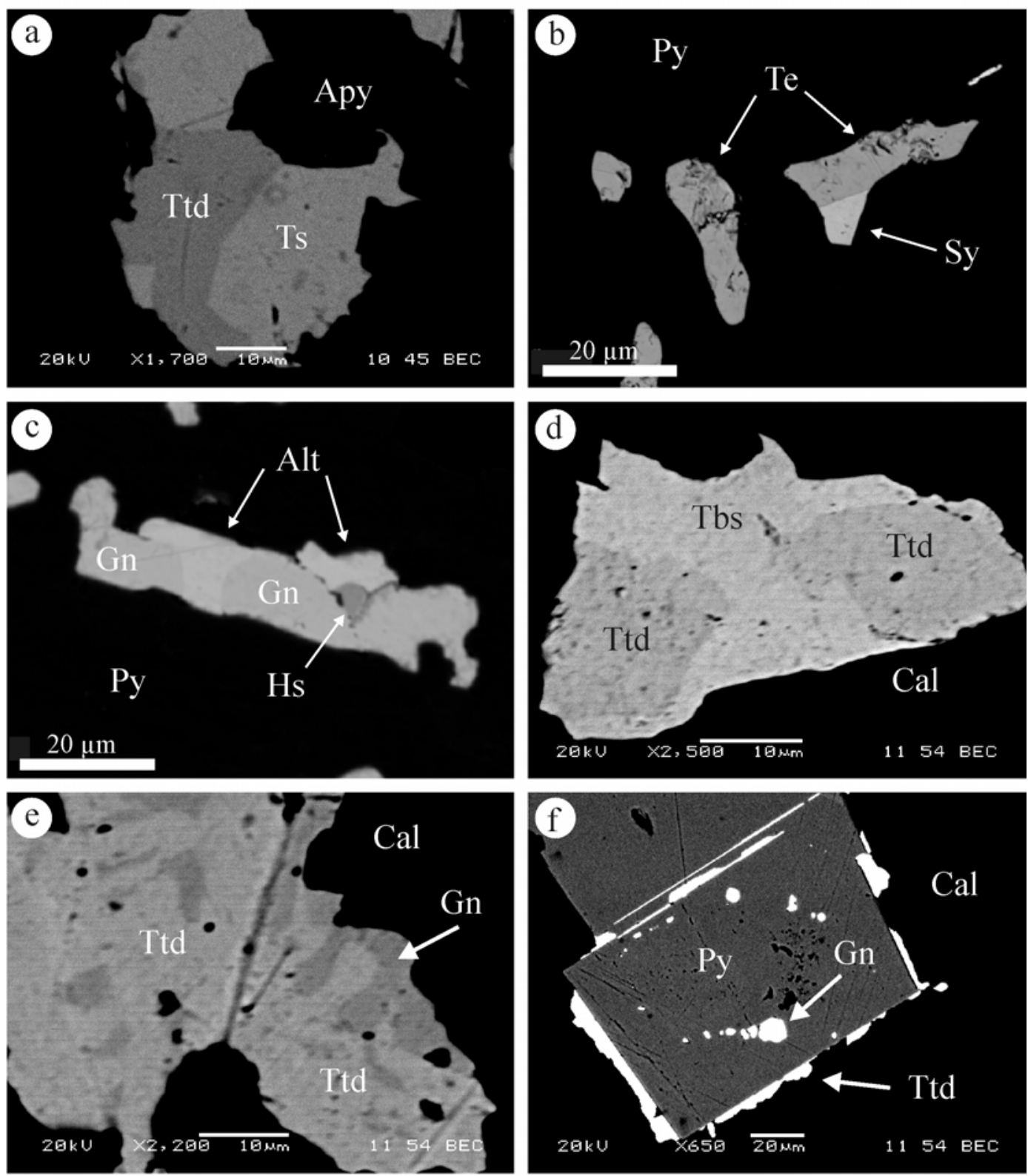

FIG. 4. BSE images showing the habit and association of Bi-tellurides in Larga ores. (a) Association of tetradymite (Ttd) and tsumoite (Ts) as inclusions within arsenopyrite (Apy) in vein ores. Note curvilinear equilibrium boundary between the two Bi-minerals. Sample: 3M (Vein 37 at $625 \mathrm{~m}, 0$ Vest gallery). (b) Association of sylvanite (Sy), native tellurium (Te) and tellurobismuthite (Tbs) within pyrite (Py). Sample: 3M (Vein 37 at $625 \mathrm{~m}, 0$ Vest gallery). (c) Assemblage containing coexisting altaite (Alt) and galena (Gn), with minor hessite (Hs). Sample: 881 (skarn, Padina gallery). (d) Equilibrium association of tetradymite (Ttd) and tellurobismuthite (Tbs) in calcite (Cal) from skarn ores. Sample: 12P (skarn, Padina gallery). (e) Larger grain of tetradymite (Ttd) within calcite from skarn ores, containing exsolved galena (Gn). Sample: 12P (skarn, Padina gallery). ( $f$ ) Narrow rim of tetradymite (Ttd) surrounding pyrite $(\mathrm{Py})$ in calcite $(\mathrm{Cal})$ from skarn ores. Gn: galena. Sample: 12P (skarn, Padina gallery). 


\section{Composition}

Compositional data for tetradymite and tsumoite from the veins are summarized in Table 1 and plotted on Fig. 6. All tetradymite analyses display the same slight enrichment of $(\mathrm{S}+\mathrm{Se})$ relative to Te that is seen in almost all published analyses for the mineral (Cook et al., in review). Analysed tetradymite compositions contain up to 0.3 atoms per formula unit (a.p.f.u.) Se, and plot along the tetradymite-kawazulite join (Fig. 6b). Some tetradymite contains several wt. $\% \mathrm{~Pb}$, attributable to sub- $\mu \mathrm{m}$ inclusions of galena. Co-existing tsumoite typically has a $\mathrm{Bi} / \mathrm{Te}$ ratio of $\sim 0.90-0.97$, consistent with the divergence from stoichiometry commonly seen in this mineral (e.g. Bayliss,
1991). Tetradymite from the skarn mineralization shows a similar distribution (Fig. 6) as in the vein ores, whereas the co-existing tellurobismuthite is effectively stoichiometric $\mathrm{Bi}_{2} \mathrm{Te}_{3}$. Rucklidgeite from the Trîmpoiele porphyry body contains $\mathrm{Pb}$, with limited variation in composition between $\left(\mathrm{Pb}_{0.82-0.87} \mathrm{Bi}_{2.11-2.16}\right)_{3}(\mathrm{Te}, \mathrm{Se}, \mathrm{S})_{4}$, and no $\mathrm{Ag}$ present (cf. Kase et al., 1993). Conspicuous, however, is the presence of $(\mathrm{Se}+\mathrm{S})$ in all analyses, between 0.1 and 0.3 a.p.f.u. (Table 1).

\section{Bismuth sulphosalts}

Mineralogy

Bi-sulphosalts are rare but persistent accessories of both vein and skarn ores exposed on the Horia
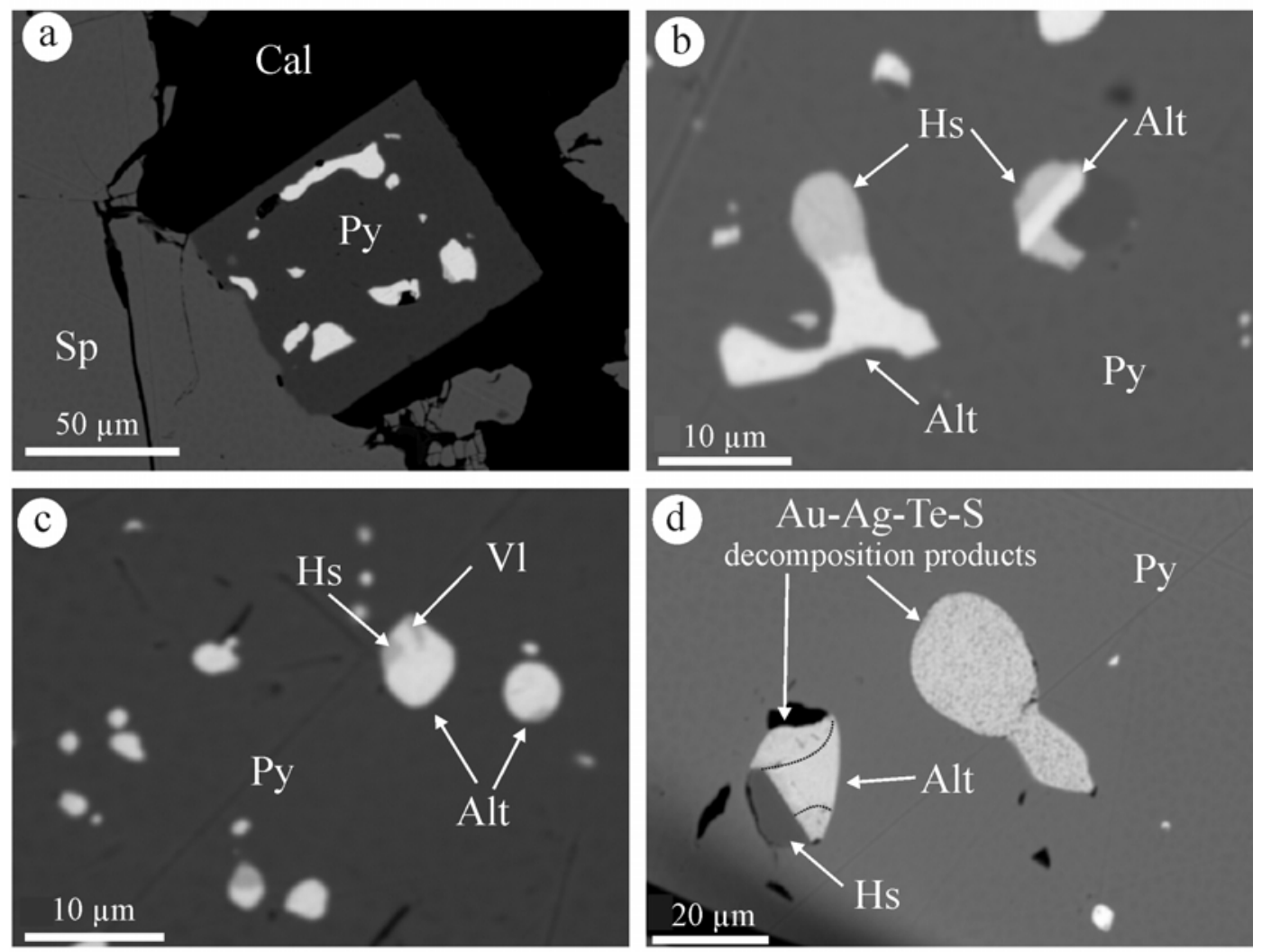

FIG. 5. BSE images showing the habit and association of Bi-tellurides in 'geode' type ores; all from sample: 71 (0 Est gallery). (a) Included blebs of tellurides (bright white) within pyrite (Py). Sp: sphalerite; Cal: calcite. (b) Composite inclusions of hessite (Hs) and altaite (Alt) within pyrite (Py). (c) Similar bleb-like telluride inclusions within pyrite (Py), consisting of hessite (Hs), altaite (Alt) and volynskite (V1). (d) Composite, bleb-like inclusions in pyrite (Py), consisting of hessite (Hs), altaite (Alt) and a decomposition intergrowth with a bulk composition approximating to

$\mathrm{Ag}_{3} \mathrm{Au}(\mathrm{S}, \mathrm{Te})_{2}$. Note curvilinear equilibrium boundaries. 
TABLE 1. Electron microprobe analyses of Bi-tellurides and tellurosulphides.

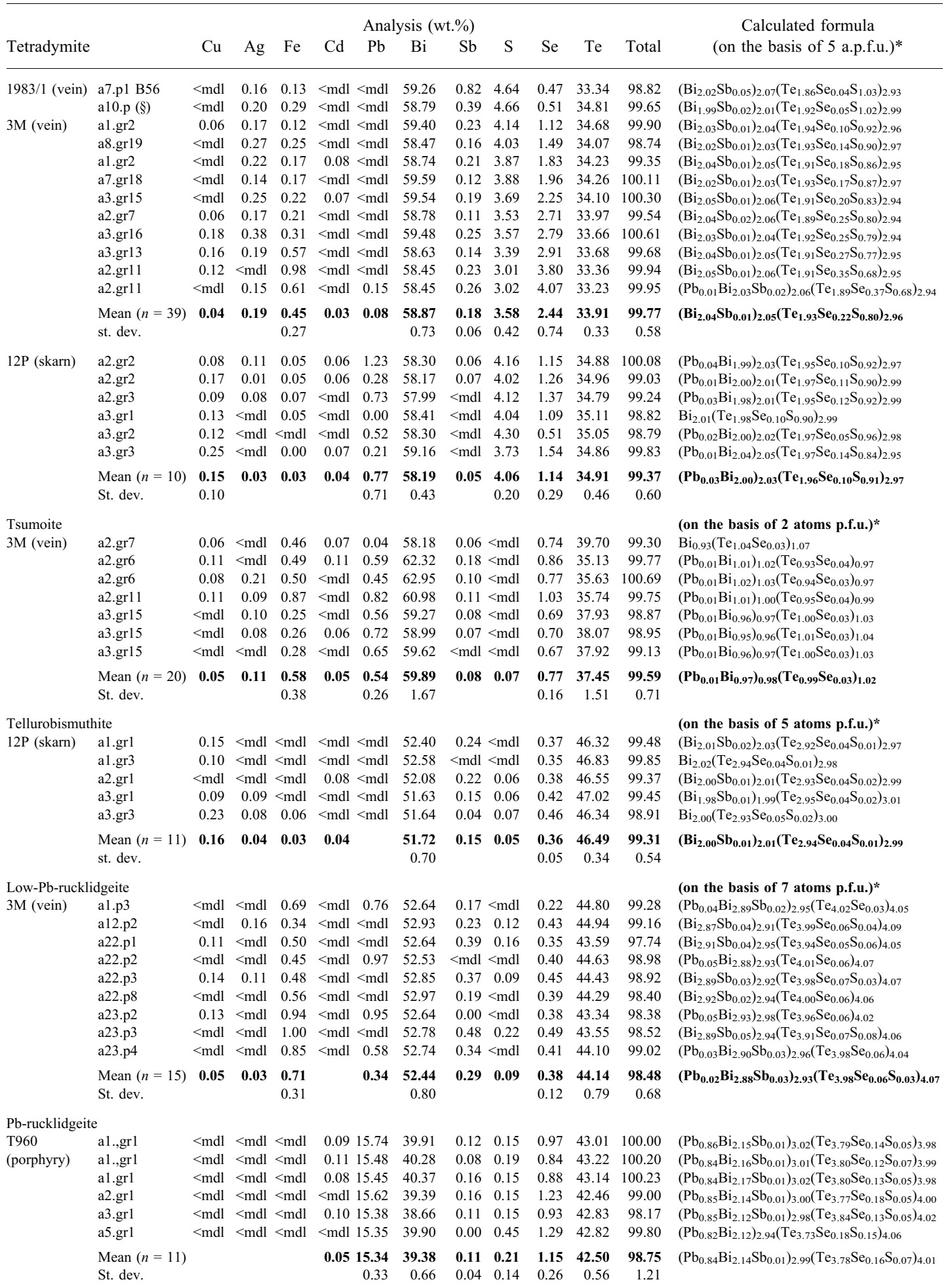

all analyses made at NHM (except $\S)$

* formula calculation excludes minor $\mathrm{Ag}, \mathrm{Cu}$ and $\mathrm{Fe}$ 


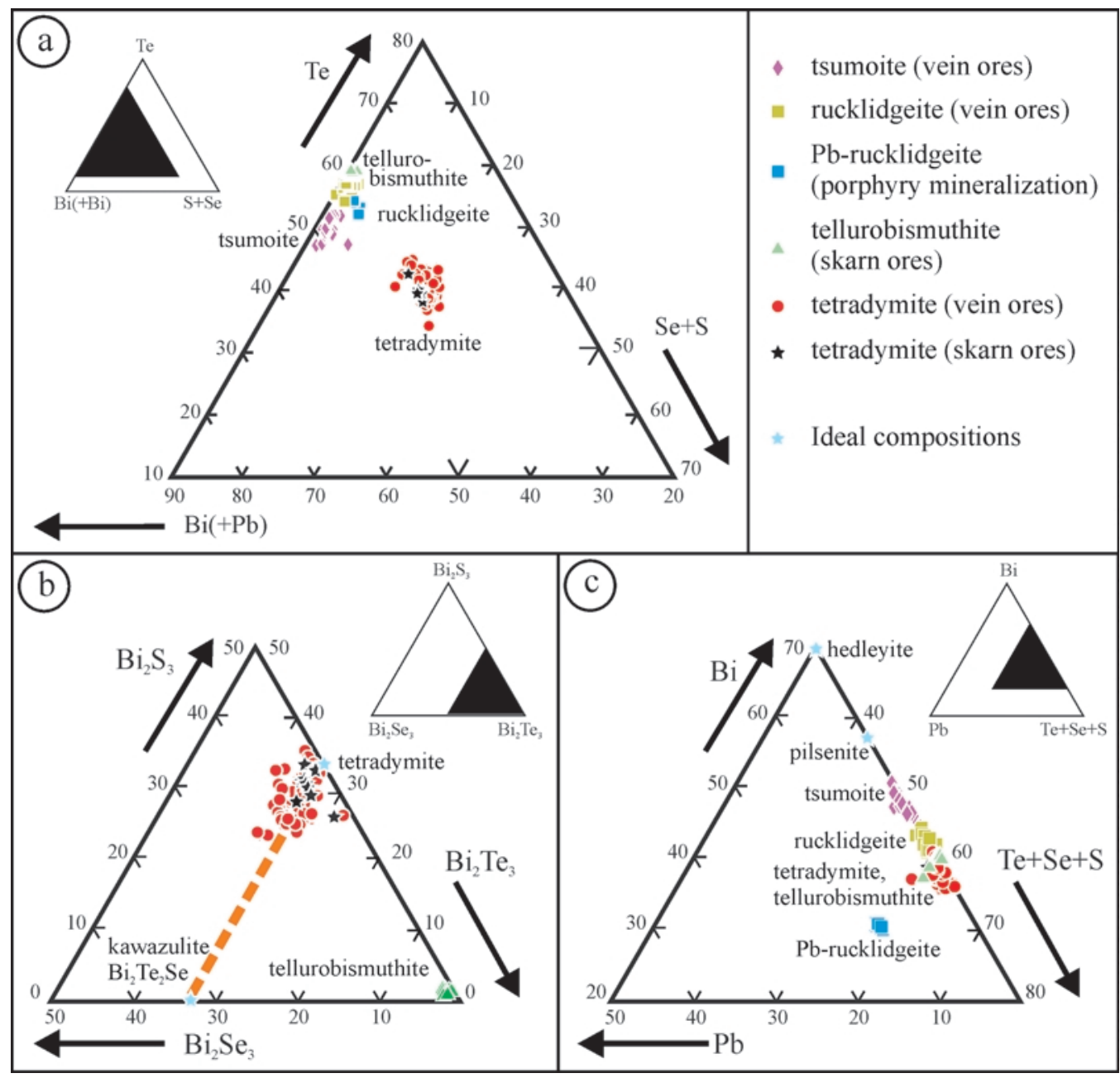

FIG. 6. (a) Composition of Bi-tellurides/tellurosulphides from Larga (tetradymite, tsumoite, tellurobismuthite, rucklidgeite), plotted in terms of $\mathrm{Bi}(+\mathrm{Pb})-\mathrm{Te}-(\mathrm{S}+\mathrm{Se})$. (b) Composition of tellurides and tellurosulphides in the $\mathrm{Bi}_{2} \mathrm{Te}_{3}-\mathrm{Bi}_{2} \mathrm{Se}_{3}-\mathrm{Bi}_{2} \mathrm{~S}_{3}$ system demonstrating the extent of solid solution along the $\mathrm{Bi}_{2} \mathrm{Te}_{2} \mathrm{~S}_{-} \mathrm{Bi}_{2} \mathrm{Te}_{2} \mathrm{Se}$ join between tetradymite, $\mathrm{Bi}_{2} \mathrm{Te}_{2} \mathrm{~S}$ and kawazulite, ideally $\mathrm{Bi}_{2} \mathrm{Te}_{2} \mathrm{Se}$. (c) Compositional variation expressed in terms of $\mathrm{Bi}-\mathrm{Pb}$ $(\mathrm{S}+\mathrm{Se}+\mathrm{Te}$ ), demonstrating compositions of $\mathrm{Pb}$-free rucklidgeite (vein ores) and rucklidgeite (porphyry mineralization).

level $(+516 \mathrm{~m})$, where they occur as elongate, $<100 \mu \mathrm{m}$ diameter inclusions within chalcopyrite, pyrite and galena (Fig. 7a). Sulphosalts are not seen in the altered skarn ('geode' area) or Cloşca veins. Lillianite homologues, lillianite, gustavite, heyrovskite and treasureite (?), are the dominant species identified, with subordinate amounts of bismuthinite derivatives, commonly intergrown with, or exsolved from the lillianite homologues (Fig. 7a). Bismuthinite derivatives (aikinite, krupkaite, bismuthinite) rarely exceed $10 \mu \mathrm{m}$ in diameter. Cosalite is a minor constituent of some assemblages. Lillianite homologues are present as intergrowths of two or more different compositions. Within the Padina skarn mineralization, lillianite homologues form larger $(200-300 \mu \mathrm{m})$, generally monomineralic intergrowths filling cavities, together with galena, within pyrite (Fig. $7 b$ ). We note a pavonite homologue as a minor component in a single sample. The mineral occurs as inclusions in pyrite, associated with lillianite. 

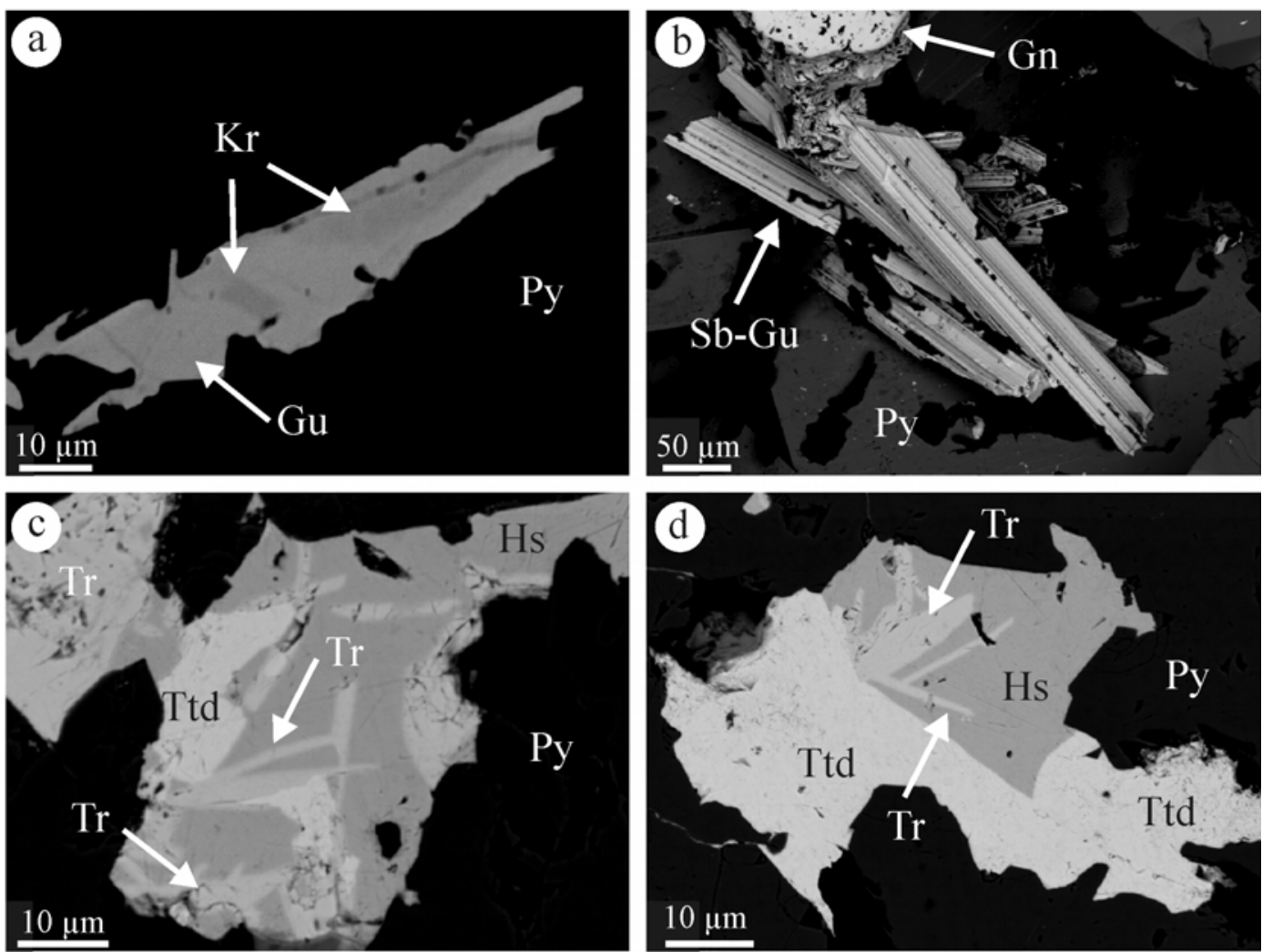

FIG. 7. BSE images showing the habit and association of Bi-sulphosalts in Larga ores. (a) Gustavite (Gu) as a lamellar inclusion in pyrite (Py) and containing exsolution of krupkaite ( $\mathrm{Kr}$ ). Sample: 145d (Padina vein). (b) Coarse crystals of Sb-gustavite (Sb-Gu), within a cavity (dark areas) on a polished specimen. Gn: galena, Py: pyrite. Sample: 145d (Padina vein). (c) Treasureite (Tr) as small elongate blades within hessite (Hs), intergrown with tetradymite (Ttd), enclosed within pyrite (Py). Sample: 1983/1 (Vein 37, $625 \mathrm{~m}$ on 0 Vest gallery). (d) Similar assemblage as in c. Note the apparent equilibrium boundaries between treasureite and hessite. Sample: 1983/1 (Vein 37, $625 \mathrm{~m}$ on 0 Vest gallery).

In the case of the vein mineralization, an intimate and apparently equilibrium assemblage of a conspicuous tabular sulphosalt (treasureite?), that occurs as masses $10-20 \mu \mathrm{m}$ in size, together with tetradymite and hessite is seen (Fig. $7 c, d$ ).

\section{Composition}

The ${ }^{4} \mathrm{~L}$ lillianite homologues (lillianite and gustavite, commonly co-existing) display variable contents of both $\mathrm{Se}$ and $\mathrm{Sb}$, ranging from virtually $\mathrm{Se}-$ and/or Sb-free to substituted varieties with $\mathrm{Se} /$ $(\mathrm{Se}+\mathrm{S})$ up to 0.22 and $\mathrm{Sb} /(\mathrm{Sb}+\mathrm{Bi})$ up to 0.34 , respectively (Table 2). Sb-bearing phases occur in both vein and skarn, but are particularly abundant in the skarn ores, which are also richer in Se. Se-rich compositional varieties generally contain little or no Sb. Unlike lillianite-gustavite, the less abundant, ${ }^{7} \mathrm{~L}$ homologue (heyrovskýite) appears only with an Sb-rich composition in the skarn. The microanalytical data set (Fig. 8) and highmagnification SEM investigations show abundant evidence for intergrowths of ${ }^{4} \mathrm{~L}$ and ${ }^{7} \mathrm{~L}$ homologues at, or below the scale of the microprobe beam, and possibly extending down to the lattice scale implying order-disorder (OD), (cf. Pring et al., 1999), with many analyses plotting on a diagonal line between the ${ }^{4} \mathrm{~L}$ and ${ }^{7} \mathrm{~L}$ compositional lines (Fig. 8).

The mineral phase coexisting with hessite and intimately associated with tetradymite is compositionally distinct and contains more $\mathrm{Ag}$ than in gustavite, and also does not indicate mixing of different order homologues. The mineral, which 
N. J. COOK AND C. L. CIOBANU

\begin{tabular}{|c|c|c|c|c|c|c|}
\hline 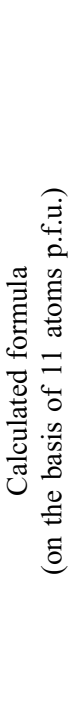 & 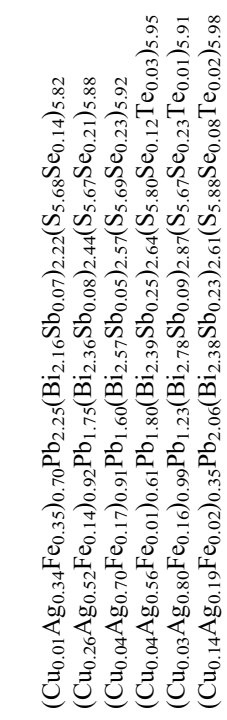 & 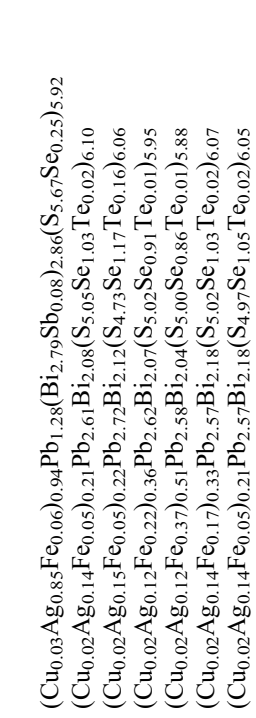 & 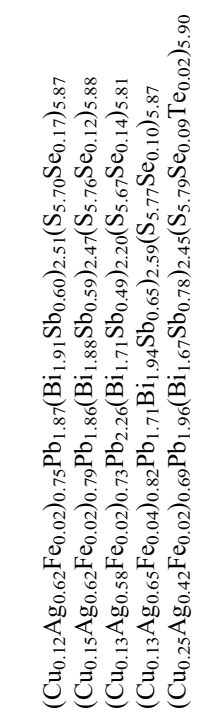 & 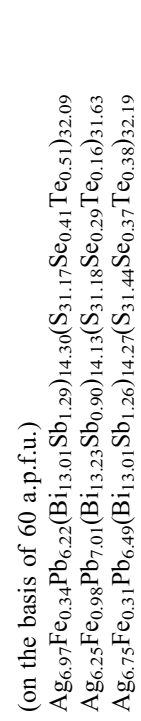 & 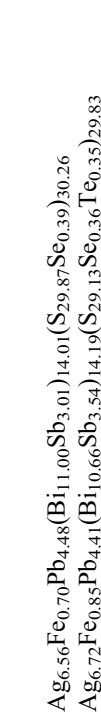 & 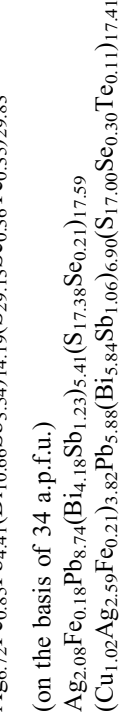 \\
\hline 亚 & 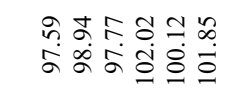 & 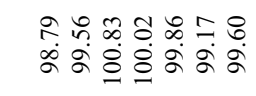 & 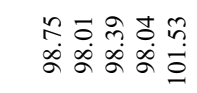 & 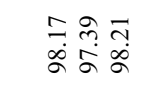 & 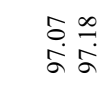 & 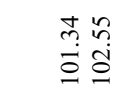 \\
\hline$\ddot{\oplus}$ & 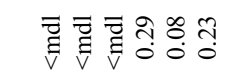 & 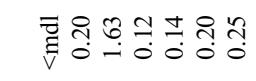 & 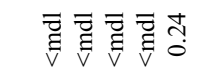 & 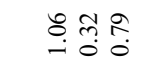 & 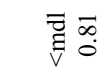 & \\
\hline$\ddot{~}$ & 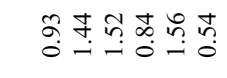 & 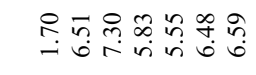 & 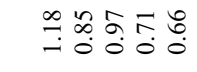 & $\hat{n} \tilde{n} \stackrel{\infty}{0} \stackrel{\infty}{0}$ & 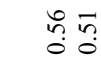 & \\
\hline is & 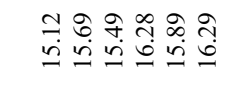 & 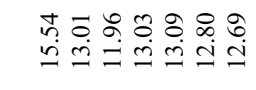 & 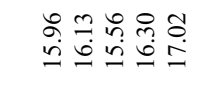 & 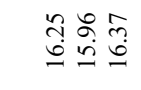 & 等 & \\
\hline & 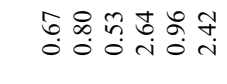 & 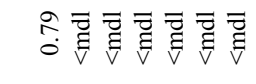 & 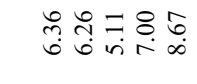 & 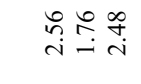 & $\underset{\sim}{\infty} \underset{0}{\infty} \underset{\sim}{\infty}$ & \\
\hline $\begin{array}{l}3 \\
\frac{n}{\infty} \\
\frac{0}{2}\end{array}$ & 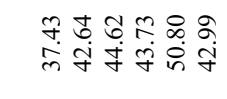 & 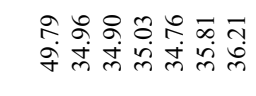 & 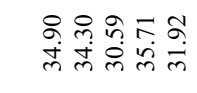 & 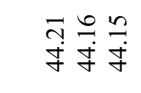 & 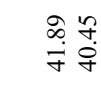 & $\begin{array}{l}e \\
\dot{2}\end{array}$ \\
\hline$\sum_{2}$ & 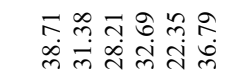 & 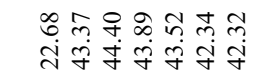 & 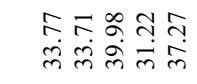 & 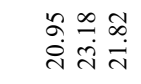 & 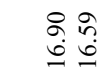 & \\
\hline I & to & 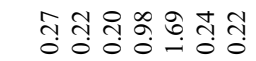 & $\exists=\frac{\infty}{0}=\frac{\pi}{0}$ & 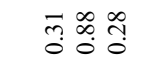 & $\begin{array}{ll}\pi & \infty \\
0 & \infty \\
0\end{array}$ & \\
\hline 20 & 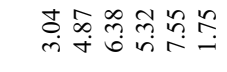 & 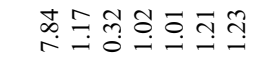 & 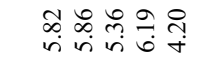 & 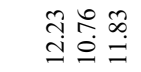 & $\begin{array}{l}\infty \\
\stackrel{\infty}{\sim} \stackrel{\infty}{=}\end{array}$ & \\
\hline J & 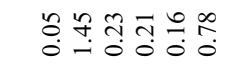 & 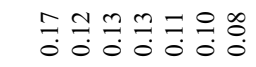 & 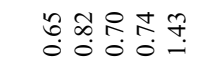 & 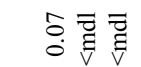 & $\bar{z} \bar{\nabla}$ & \\
\hline & 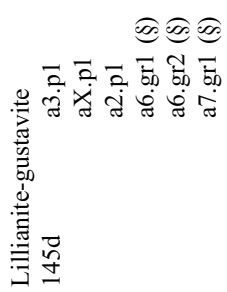 & 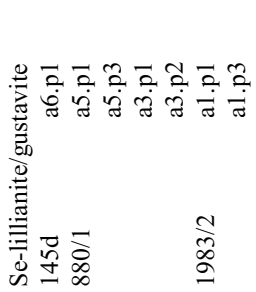 & 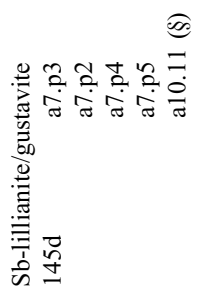 & 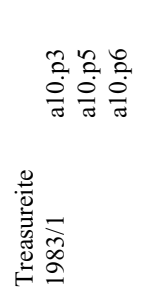 & 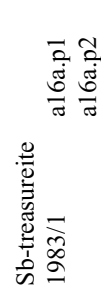 & 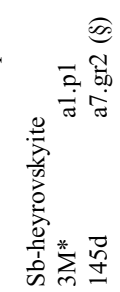 \\
\hline
\end{tabular}




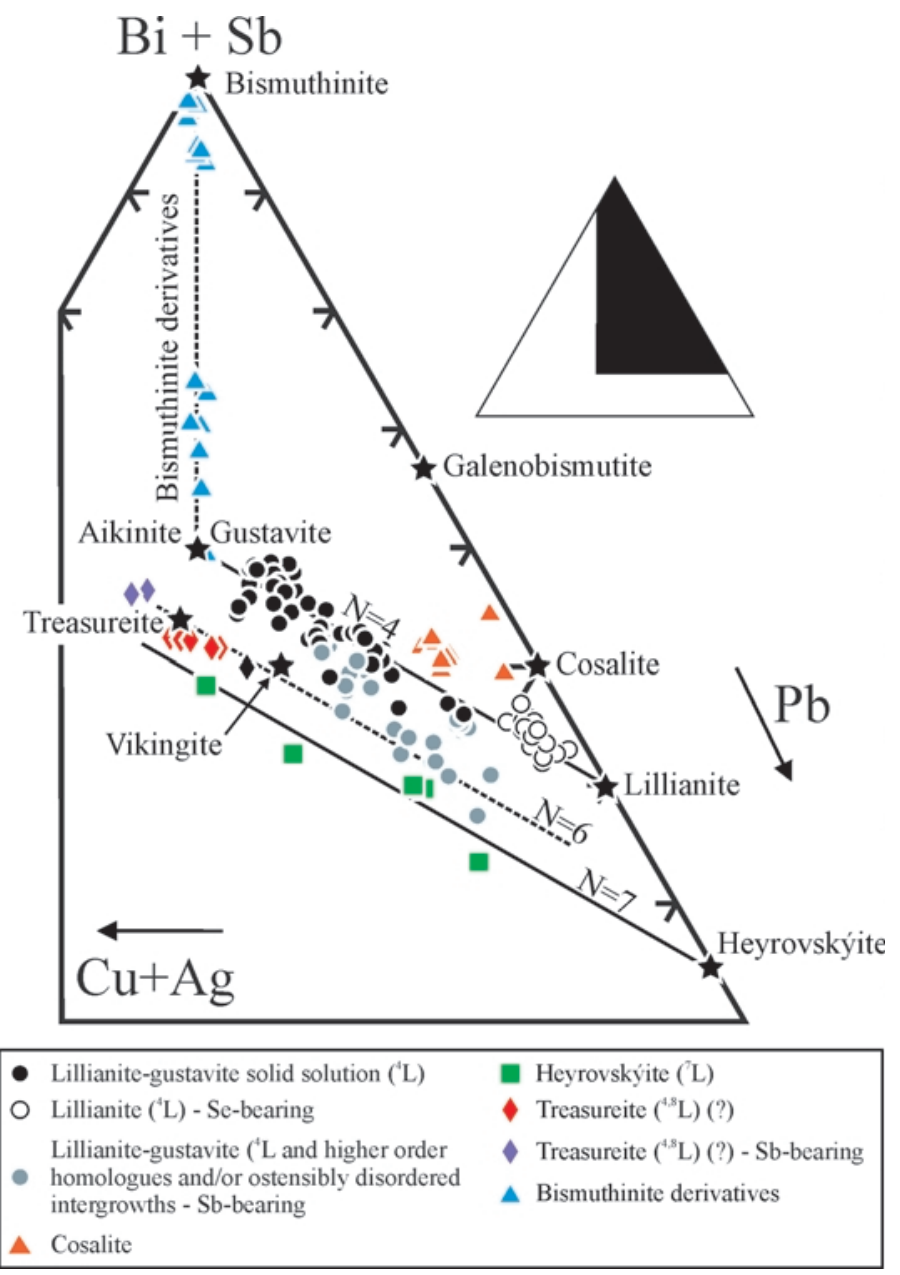

Fig. 8. Plot of compositions in $(\mathrm{Cu}+\mathrm{Ag})-\mathrm{Pb}-(\mathrm{Bi}+\mathrm{Sb})$ ternary space.

we tentatively identify as treasureite, ideally $\mathrm{Ag}_{7} \mathrm{~Pb}_{6} \mathrm{Bi}_{15} \mathrm{~S}_{32}$, contains more moderate concentrations of $\mathrm{Sb}$ and negligible $\mathrm{Se}$, and conforms closely to the composition of this rare remember of the lillianite homologous series with $\mathrm{N}_{\text {chem }}=6$, i.e. ${ }^{4,8} \mathrm{~L}$.

The bismuthinite derivatives aikinite $\left(\mathrm{BD}_{\sim 94}\right)$, krupkaite $\left(\mathrm{BD}_{\sim 51}\right)$ and bismuthinite $\left(\mathrm{BD}_{\sim 9}\right)$ are minor components and appear as $<5 \mu \mathrm{m}$ lamellar inclusions within lillianite. An additional sulphosalt, $\mathrm{Ag}_{0.11} \mathrm{Cu}_{0.02} \mathrm{~Pb}_{1.54} \mathrm{Bi}_{2.30} \mathrm{~S}_{4.93}$, is a minor phase in the assemblage and probably represents a substituted cosalite.

Compositions of the pavonite homologue are given in Table 3. Members of this mineral group are difficult to identify on the basis of microprobe analyses alone (e.g. Karup-Møller \& Makovicky, 1979). Nevertheless, the relatively low $\mathrm{Cu}$ and $\mathrm{Pb}$ contents and tight cluster on the compositional plot in $\mathrm{Bi}-\mathrm{Ag}-(\mathrm{Pb}+\mathrm{Cu})$ space (Fig. 9) give us confidence to consider the mineral in question as the ${ }^{5} \mathrm{P}$ homologue, pavonite.

\section{Discussion}

In contrast to the abundance of Bi-sulphosalts described from deposits of the Banatitic Magmatic and Metallogenetic Belt of Romania, Serbia-Bulgaria (Ciobanu et al., 2002), few have been reported previously from Neogene mineralization in Romania. The only other reported occurrences, with corroborative electron micro- 
N. J. COOK AND C. L. CIOBANU

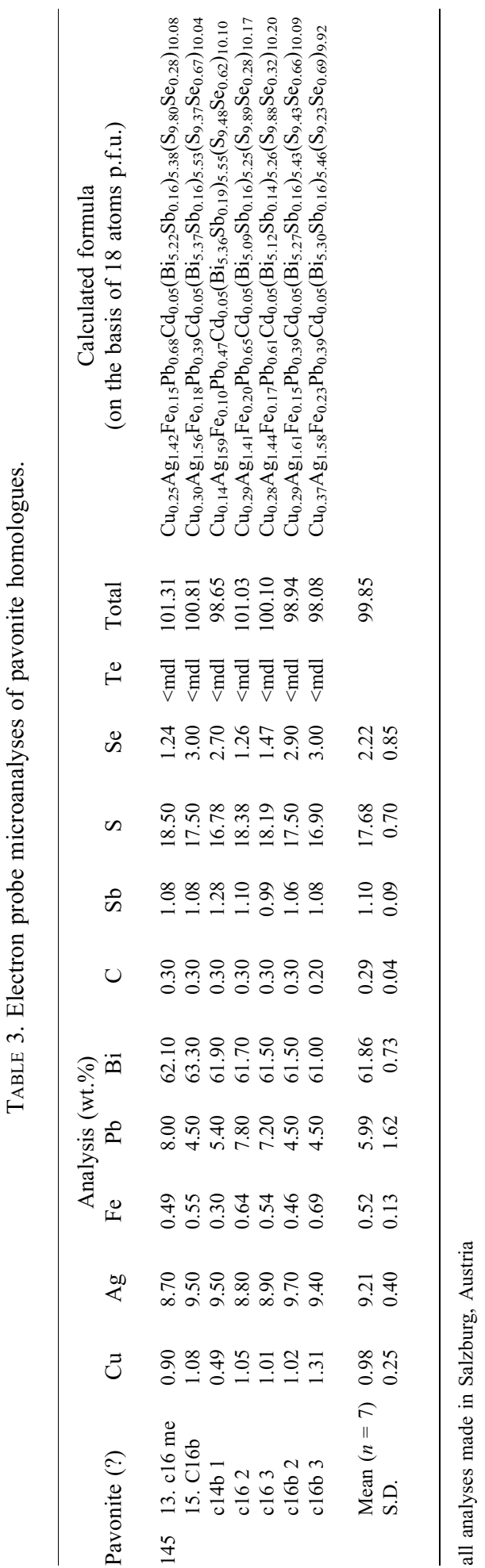



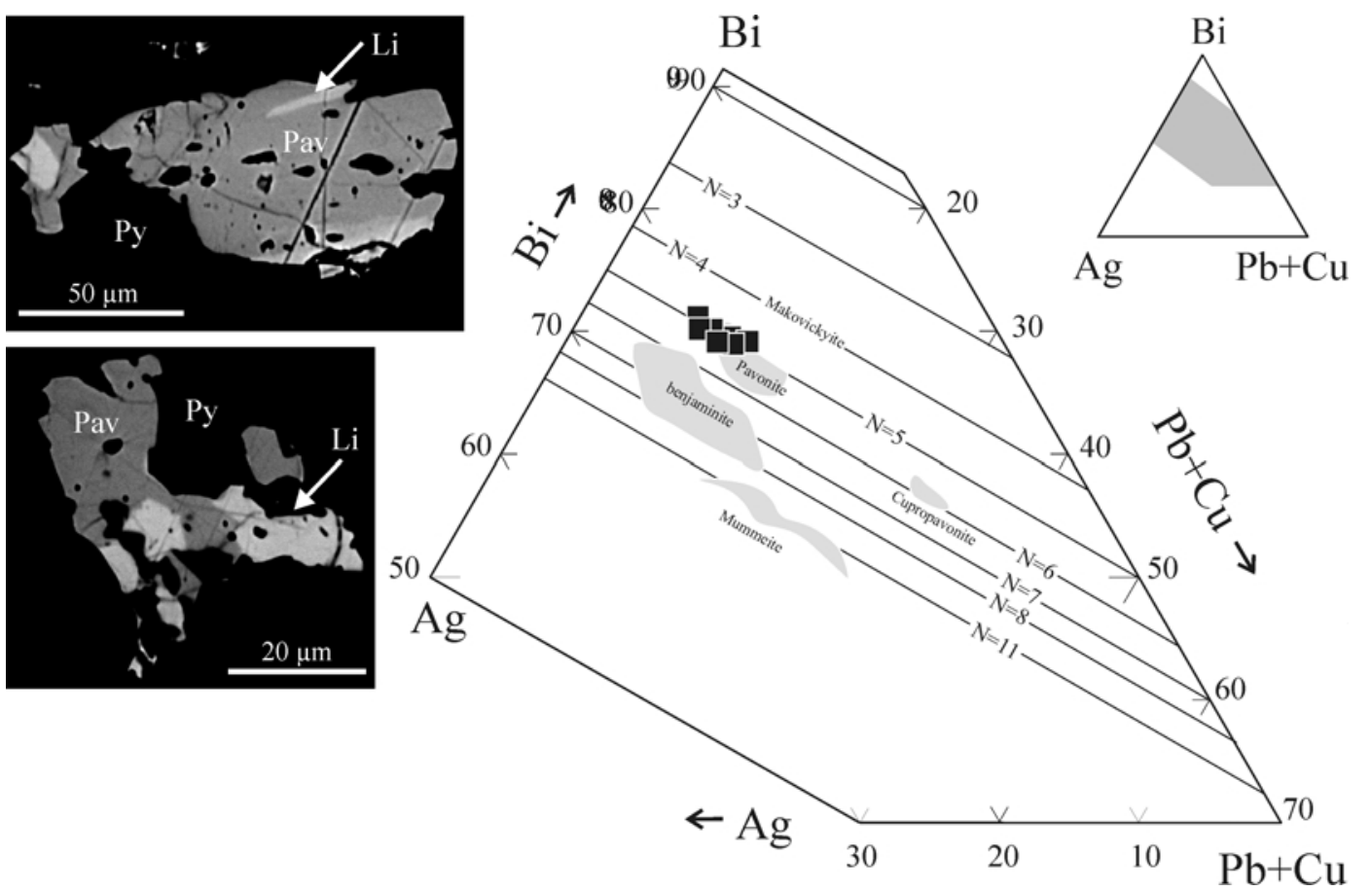

FIG. 9. Compositions of pavonite homologue ( ${ }^{5} \mathrm{P}$, pavonite? $)$ plotted in $\mathrm{Bi}-\mathrm{Ag}-(\mathrm{Pb}+\mathrm{Cu})$ ternary space. Two backscattered electron images show the morphology of the mineral. Pav: pavonite (?), Li: lillanite, Py: pyrite.

probe data, are within the Băiuţ-Văratec and Nistru deposits of the Baia Mare district, and the Toroiaga deposit, Baia Borşa district, in northern Romania (Cook, 1997, 1998; Damian and Cook, 1999; Damian and Costin, 1999). There are similarities between these and the Larga occurrence, both in the dominance of lillianite homologues, typical occurrence within $\mathrm{Au}$ enriched pyrite ( \pm arsenopyrite) ores, and the variable but persistent substitution of $\mathrm{Se}$ and $\mathrm{Sb}$ within the Bi-sulphosalts. This study confirms the earlier opinion that, in the Carpathian-Balkan orogens, Bi-sulphosalts are not restricted to Upper Cretaceous 'banatite' metallogenesis (e.g. Cioflica et al., 1995; Cook et al., 2002), but are also components of younger mineralization.

The fact that Bi-sulphosalts are more widespread than previously recognized, and the intimate relationships with Bi-tellurides/tellurosulphides, with their distinct speciation trends, allows a number of observations to be made. Despite the fact that they occur as small or very small grains, tellurides, selenides and sulphosalts, as well as their mutual relationships, can be valuable indicators of physicochemical conditions of formation in ore systems, because they are highly sensitive to changes in temperature, Eh-pH conditions, $f_{\mathrm{O}_{2}}$ and $f_{\mathrm{S}_{2}}$.

Considering the dominant telluride mineralogy at different vertical levels in the hydrothermal system, Larga-Faţa Băii can be viewed as a strongly zoned system with respect to $f_{\mathrm{Te}_{2}}$, and also to temperature. Whereas Au-tellurides and native tellurium are stable at the uppermost levels, on Horia $(+516 \mathrm{~m})$ level, $f_{\mathrm{Te}}$, is below the stability limit for calaverite, yet still within the stability field for tellurobismuthite and hessite. The commonly observed assemblages containing both abundant altaite and galena, sometimes sharing grain boundaries (e.g. Fig. 4c), allow a narrow domain in $f_{\mathrm{Te}_{2}}-f_{\mathrm{S}_{2}}$ space to be constrained along the stability boundary between the two minerals. The absence of primary acanthite, native-Ag or -Bi allows some constraints to be made on $f_{\mathrm{Te}_{2}}$ and $f_{\mathrm{S}_{2}}$. Applying the approach of Afifi et al. $(1988 a, b)$, this is interpreted to reflect an increase in $\log f_{\mathrm{Te}_{2}}$ from below -10 to $>-5$, vertically upward from the fluid source, at $\log f_{\mathrm{S}_{2}}$ 
of around -15 to -10 (Fig. 10). The co-existence of Bi-sulphosalts and -tellurides/tellurosulphides in the Larga veins is controlled by the parameters of the pyrite-buffered environment, close to the pyrrhotite stability field. Co-existing tellurides and tellurosulphides (tetradymite, tsumoite) have $\mathrm{Me} / \mathrm{Te}(+\mathrm{Se}+\mathrm{S}) \leqslant 1$. Such assemblages indicate relatively high $f_{\mathrm{S}_{2}}$ conditions, coupled with still relatively high $f_{\mathrm{Te}_{2}}$. Thermodynamic data are missing for the three-component $\mathrm{Pb}-\mathrm{Bi}-\mathrm{Te}$ system, precluding correlation of telluride assemblage with $f_{\mathrm{Te}_{2}}$ and $f_{\mathrm{S}_{2}}$ to the porphyry mineralization. The presence of altaite and rucklidgeite, which also has $\mathrm{Bi} /(\mathrm{Te}+\mathrm{Se}+\mathrm{S})<1$, suggests that the lowest levels of the system formed at comparable $f_{\mathrm{Te}_{2}}$ conditions as the ores of the Horia level.

The association between tetradymite and $\mathrm{Bi}$ sulphosalts (e.g. aikinite-bismuthinite and lillianite series), commonly with equilibrium grain boundaries is also significant, since synthetic experiments show extensive solid solution in the $\mathrm{Bi}_{2} \mathrm{~S}_{3}-\mathrm{Bi}_{2} \mathrm{Te}_{3}$ system, e.g. $43-66 \mathrm{~mol} . \% \mathrm{Bi}_{2} \mathrm{Te}_{3}$ at $500^{\circ} \mathrm{C}$ (Yusa et al., 1979). The presence of minor $\mathrm{Pb}$ within the 'droplets' encapsulated in pyrite, either as rucklidgeite solid solution $(\mathrm{Pb}, \mathrm{Bi})_{3} \mathrm{Te}_{4}$ or sub-microscopic blebs of galena in tetradymite, favours formation of Bi-sulphosalts and/or Bi-tellurosulphides since character- istic order-disorder (OD) mechanisms in these minerals can be accessed to accommodate nonstoichiometry (cf. Bayliss, 1991). Both Bi-tellurosulphides and sulphosalts are commonly nonstoichiometric, a fact that can be correlated with OD in both series. If tetradymite is absent, equilibrium formation of $\mathrm{Bi}$-sulphosalts is normally precluded.

Similar Bi-mineral assemblages may be expected at comparable, intermediate levels within other deposits in the region, e.g. Săcărîmb, Musariu, Măgura-Hondol), 200-400 m below those ores rich in Au-tellurides (+ native tellurium, telluroantimony etc.) at upper levels, and which contributed much of the wealth, both economic and mineralogical, for which the area is known. The occurrence of pilsenite, $\mathrm{Bi}_{4} \mathrm{Te}_{3}$, ingodite, $\mathrm{Bi}(\mathrm{Te}, \mathrm{S})$, and aleksite, $\mathrm{PbBi}_{2} \mathrm{Te}_{2} \mathrm{~S}_{2}$, from Săcărîmb (Şimon and Alderton, 1995a; Shimizu et al., 1999) corroborate this. Together, they may provide valuable information on the evolution of comparable complex, telluride-rich systems.

\section{Significance for gold enrichment}

Tellurides of bismuth, together with selenides and sulphosalts commonly form multi-phase eutectic/

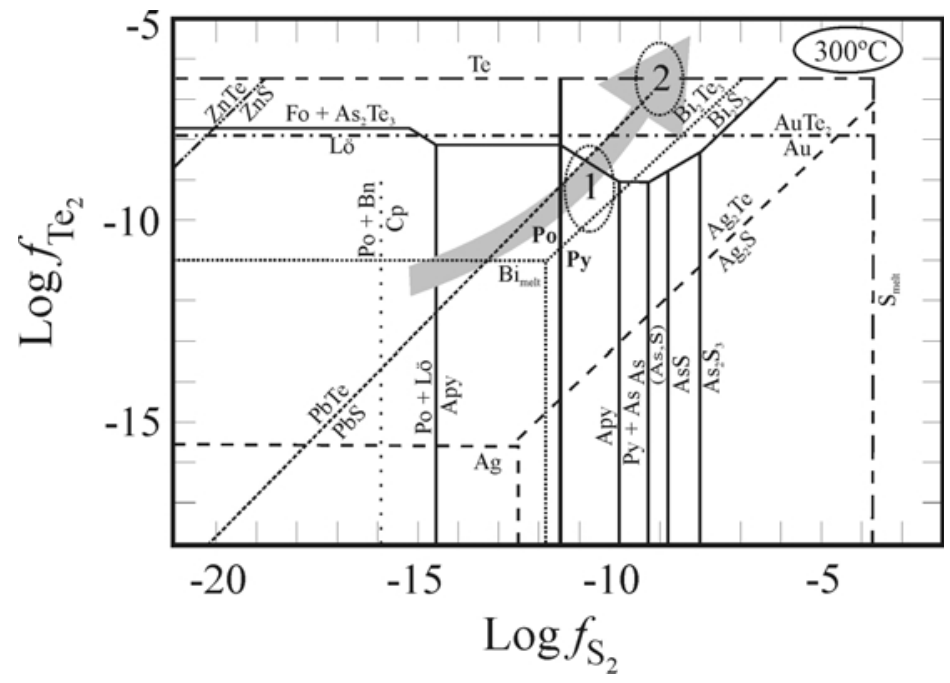

FIG. 10. Telluride-sulphide stability diagram at $300^{\circ} \mathrm{C}$ in $f_{\mathrm{Te}_{2}}-f_{\mathrm{S}_{2}}$ space, after Afifi et al. $(1988 a, b)$, for mineral phases relevant to the Larga system. The grey arrow indicates the trend of mineralizing conditions from the base of the system upwards. Domains marked ' 1 ' and ' 2 ' correspond to the intermediate (i.e. Horia $+516 \mathrm{~m}$ ) and uppermost levels respectively. In the latter, Au-telluride-rich levels, calaverite and native tellurium are stable. Based on prevailing major and accessory assemblages. Abbreviations: Py: pyrite, Po: pyrrhotite, Cp: chalcopyrite, Bn: bornite, Apy: arsenopyrite, Lö: löllingite, Fo: frohbergite. 
equilibrium assemblages at Larga. This feature indicates that, in many cases, extraction from mineralizing fluids closely parallels iss formation in the $\mathrm{Cu}-\mathrm{Fe}-\mathrm{S}$ system, in that they are extracted in the same way as Au-Bi-Te-S $\mathrm{S}_{\mathrm{ss}}$ droplets and crystallize in equilibrium with the host (Ciobanu and Cook, 2002). The pronounced association with gold within the 'droplets' is because it can be incorporated into Bi-melt at high $a \mathrm{Bi}$. Evidence for extraction of gold in droplets is seen particularly explicitly in the 'geode' ores. However, in a pyrite-buffered environment, native $\mathrm{Bi}$ and maldonite $\left(\mathrm{Au}_{2} \mathrm{Bi}\right)$ are not stable. These observations are consistent with recent experiments on the partitioning of $\mathrm{Au}$ between hydrothermal solutions and liquid $\mathrm{Bi}$ showing that, above its melting point $\left(271^{\circ} \mathrm{C}\right)$, liquid $\mathrm{Bi}$ is a powerful scavenger for $\mathrm{Au}$ from $\mathrm{Au}$-undersaturated hydrothermal solutions (Douglas et al. 2000).

\section{Constraints on temperature}

Although the trace mineralogy permits LargaFaţa Băii to be viewed as a strongly zoned system with respect to the speciation of $\mathrm{Au}-$ and $\mathrm{Bi}$ tellurides, some constraints can also be placed on temperature across the vertical extent of the Larga system. Temperatures of $400-450^{\circ} \mathrm{C}$ at depth in the porphyry appear to extend, at least, to the intermediate (Horia) level at the onset of mineralization. The presence of iss inclusions in sphalerite from an equivalent level from Haneş (Fig. 3f), testify that temperatures of at least $334 \pm 17^{\circ} \mathrm{C}$ (Yund and Kullerud, 1966) were attained higher up in the system. The location of the iss droplets within sphalerite may actually point to deposition from a $(\mathrm{Cu}, \mathrm{Fe}, \mathrm{Zn})_{1+x} \mathrm{~S}$ intermediate solid solution at temperatures as high as $500{ }^{\circ} \mathrm{C}$. In this line, we note that Udubaşa et al. (1976) used similar arguments to suggest comparable temperatures for part of the Bocşa polymetallic mineralization at Săcărîmb. More commonly, mineralization temperatures in the range $200-300^{\circ} \mathrm{C}$ are commonly accepted for the area on the basis of fluid inclusion data (e.g. Borcoş, 1969; Alderton and Fallick, 2000).

Further evidence for elevated temperatures, at least in parts of the system, can be obtained from geothermometry using compositions of sphaleritestannite pairs in the 'geode' ore (e.g. Shimizu and Shikazono, 1985). The data (Fig. 11) give temperatures between $450^{\circ} \mathrm{C}$ and $350^{\circ} \mathrm{C}$, reflecting points along the cooling path at which chemical equilibrium was attained. Generally, smaller sphalerite-stannite grains (e.g. Fig. 11a) give temperatures closer to $350^{\circ} \mathrm{C}$, than larger grains (e.g. Fig. 11b), where indicated temperatures are $\sim 450^{\circ} \mathrm{C}$. The tellurides themselves offer few temperature constraints, with the few potentially useful associations (e.g. association of tellurobismuthite-native tellurium forming a melt eutectic at $413^{\circ} \mathrm{C}$; Elliott, 1965), not being observed in our specimens. Additional temperature constraints can be made on the presence of relict löllingite ( \pm pyrrhotite) within arsenopyrite suggesting transition temperatures between 400 and $500^{\circ} \mathrm{C}$, given $\log f_{\mathrm{S}_{2}}$ values of around -10 (Fig. 10), (Barton and Skinner, 1969).

\section{Application to genetic model}

A tectonic model for complex porphyry copperpolymetallic vein kin deposit systems, involving structural traps and tensional shear meshes within slip-fault duplexes in a supra-subduction setting have recently been applied to the Metaliferi Mts., and the Haneş-Larga field in particular (Drew et al., 1999; Drew and Berger, 2001). We believe that our observations are fully concordant with such a model, in which volumes of hightemperature fluids were rapidly flushed upwards from an already emplaced porphyry system into a ready network of extensional and shear fractures. According to Drew and Berger (2001), this creates local "mesothermal"-like conditions and a ductile environment. Initial crystallization took place with pyrrhotite + löllingite as the stable assemblage. Subsequent inversion to a stable pyrite + arsenopyrite assemblage was accompanied by appearance of gold released from löllingite. This 'switch', equivalent to that diagnosed during retrograde metamorphism (Tomkins and Mavrogenes, 2001), can be considered as a sulphidation reaction, due to an increase in $f_{\mathrm{S}_{2}}$, coupled with a decrease in $f_{\mathrm{O}_{2}}$, drop in temperature and sudden depressurization. Simultaneously, Ag- and Bi-tellurides were extracted from fluids as Au-Bi-Te-(S) 'melts' at temperatures above the melting point of bismuth, and formed equilibrium assemblages with the bulk composition of the initial 'droplet', or alternatively, as in the 'droplets' in the 'geode' ores, decomposed during cooling (Fig. 5d). The speciation of Bi-tellurides, with $\mathrm{Bi} / \mathrm{Te}(+\mathrm{Se}+\mathrm{S})$ $\leqslant 1$ (tetradymite, tsumoite, tellurobismuthite, rucklidgeite) is consistent with a pyrite-buffered environment. 

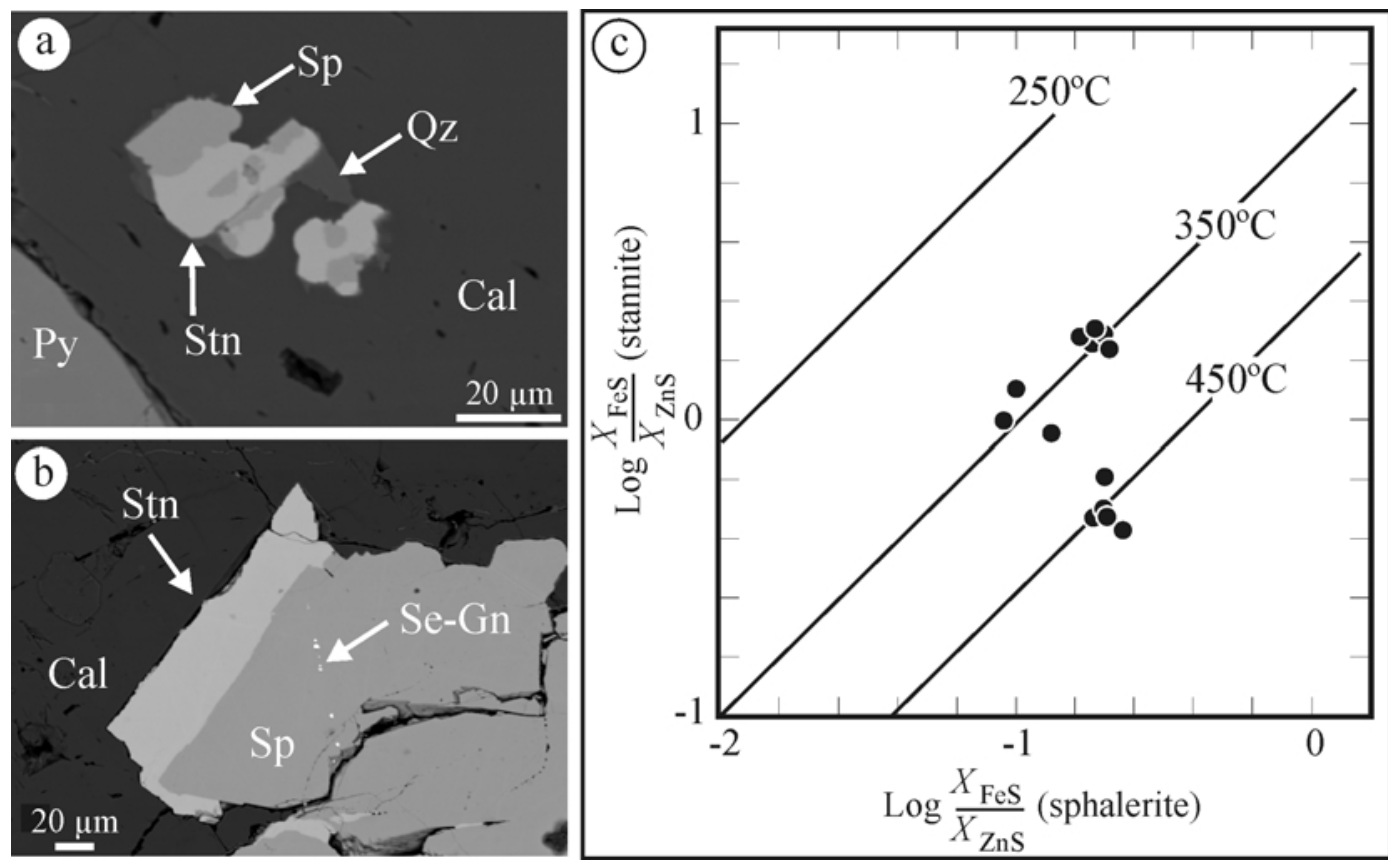

FIG. 11. Application of the geothermometric method based on the composition of coexisting stannite-sphalerite pairs in altered skarn ores from Larga. ( $a$ ) and (b) BSE images showing two examples of stannite-sphalerite pairs used for geothermometry. Abbreviations: Sp: sphalerite, Stn: stannite, Qz: quartz, Cal: calcite, Se-Gn: seleniferous galena. Sample 71 (0 Est gallery). (c) Compositional data plotted on isotherms according to the calibration of Nakamura and Shima (1982) cited by Shimizu and Shikazono (1985). Smaller grains (e.g. $a$ ), give temperatures close to $350^{\circ} \mathrm{C}$.

\section{Conclusions}

(1) Sulphosalts (dominantly lillianite homologues) and tellurides/tellurosulphides of bismuth with $\mathrm{Bi} / \mathrm{Te}(+\mathrm{Se}+\mathrm{S}) \leqslant 1$ (tetradymite, tsumoite, tellurobismuthite, rucklidgeite) are significant, abundant accessories in the median part of the Larga hydrothermal system. Stable assemblages are a function of the intermediate $f_{\mathrm{Te}_{2}}$ conditions and temperatures that exceeded $400^{\circ} \mathrm{C}$.

(2) The association of sulphosalts, tellurides and gold is controlled by the pyrite-(arsenopyrite)-buffered environment, formed by sulphidation of an initial pyrrhotite-löllingite assemblage. Sulphosalts, and to some extent tellurides, are able to access changes in fluid/ melt composition by order/disorder and nonstoichiometry.

(3) Tellurides are not restricted to high levels of the mineralized systems in the Metaliferi Mts. Both tellurides and sulphosalts groups help to define a zoned hydrothermal system, in which a marked $f_{\mathrm{Te}_{2}}$ decrease with depth reflects a variety of chemical environments, with Au-tellurides and native tellurium dominant at upper levels, Bitellurides/tellurosulphides at intermediate levels, and $\mathrm{Bi}-\mathrm{Pb}$ and $\mathrm{Pb}$-tellurides at depth.

\section{Acknowledgements}

This study forms part of a project on sulphosalts and telluride mineralogy being carried out at the Geological Survey of Norway. CLC gratefully acknowledges a NATO post-doctoral fellowship, focussing on the geological significance of sulphosalts, tellurides and selenides in a range of Au-bearing deposits. Some electron microprobe data in this publication were obtained during a visit to the EU Geochemical Facility, University of Bristol (UK). We acknowledge the support of the European Community Access to Research Infrastructure action of the Improving Human Potential Programme, contract HPRI-CT1999-00008 awarded to Prof. B.J. Wood. Other data were obtained at the Natural History Museum, London, with the financial support of 
the European Union. We are also especially grateful for access to microanalytical facilities in the Department of Mineralogy, University of Salzburg, Austria, with the kind support of Werner H. Paar and technical support from Dan Topa. Last, but not least, the constructive review by Frances Wall and comments by Guest Editor, Chris Stanley, are much appreciated.

\section{References}

Afifi, A.M., Kelly, W.C. and Essene, E.J. (1988a) Phase relations among tellurides, sulfides, and oxides: I. Thermochemical data and calculated equilibria. Economic Geology, 83, 377-394.

Afifi, A.M., Kelly, W.C. and Essene, E.J. (1988b) Phase relations among tellurides, sulfides, and oxides: II. Applications to telluride-bearing ore deposits. Economic Geology, 83, 395-404.

Alderton, D.H.M. and Fallick, A.E. (2000) The nature and genesis of gold-silver-tellurium mineralization in the Metaliferi Mountains of western Romania. Economic Geology, 95, 495-515.

Barton, P.B. and Skinner, B.J. (1969) Sulfide mineral stabilities. Pp. 278-403 in: Geochemistry of Hydrothermal Ore Deposits (H.L. Barnes, editor). Wiley, New York.

Bayliss, P. (1991) Crystal chemistry and crystallography of some minerals in the tetradymite group. American Mineralogist, 76, 257-265.

Berbeleac, I. (1986) Mineral parageneses in Tertiary gold deposits, Romania. Pp. 261-290 in: Mineral Parageneses (J.R. Craig, R.D. Hagni, W. Kiesl, I.M. Lange, N.V. Petrovskaya, T.N. Shadlun, G. Udubaşa and S.S. Augustithis, editors). Theophrastus Publications, Athens.

Berbeleac, I. and David, M. (1982) Native tellurium from Musariu, Brad region, Metaliferi Mountains, Romania. Pp. 283-295 in: Ore Genesis; the State of the Art. (G.C. Amstutz, A. El-Goresy, G. Frenzel, C. Kluth, G.H. Moh, G.H. Wauschkuhn and R.A. Zimmermann, editors). Springer, Berlin.

Berbeleac, I., Popa, T., Marian, I., Iliescu, D. and Costea, C. (1995) Neogene porphyry copper-gold, gold, and gold-bearing epithermal deposits in the South Apuseni Mountains, Romania. Proceedings, $15^{\text {th }}$ Congress, Carpathian-Balkan Geological Association, pp. 665-670.

Borcoş, M. (1969) Le controle thermodynamique dans la métallogenèse associée au volcanisme néogène des Monts Métalliferes de la Transylvanie. Annales de la Société Géologique de Belgique, 92, 307-320.

Borcoş, M. (1994) Volcanicity/metallogeny in the South Apuseni Mts. (Metaliferi Mts.). Plate Tectonics and Metallogeny in the East Carpathians and Apuseni Mts. Field Trip Guide, IGCP Project 356 (M. Borcoş and Ş. Vlad, editors), Institutul Geologic al Romaniei, Bucharest, pp. 32-38.

Borcoş, M., Gheorghita, I., Bostinescu, S. and Maties, P. (1964) Considerations on some Neogene magmatic manifestations, lineaments of the Metaliferi mountains, and on the structure of the volcanic apparatus Haneş. Dări de Seamă Comitetul Geologic, 49, 33-40 (in Romanian).

Borcoş, M., Kräutner, H.G., Udubaşa, G., Săndulescu, M., Năstăseanu, S., Biţoianu, C. (1983) Mineral Resources Map of Romania, scale 1:1,000,000, with explanatory text, $2^{\text {nd }}$ edition. Institutul Geologic al Romaniei, Bucharest.

Borcoş, M., Roşu, E., Andrei, J., Bordea, S., Găbudeanu, B. and Popescu, H. (1989) Zona Vulcanică Neogenă Zlatna-Stănija. Structural-metallogenetic map, scale 1:25,000. Unpublished map, Institutul Geologic al Romaniei, Bucharest (in Romanian).

Ciobanu, C.L. and Cook, N.J. (2002) Tellurides, selenides (and Bi-sulphosalts) in gold deposits. 11th Quadrennial IAGOD symposium Geocongress 2002, Windhoek, Namibia, July 2002. $C D$ Volume of extended abstracts. Geological Survey of Namibia.

Ciobanu, C.L., Cook, N.J. and Stein, H. (2002) Regional setting and geochronology of the Late Cretaceous Banatitic Magmatic and Metallogenic Belt. Mineralium Deposita, 37, 541-567.

Cioflica, G., Jude, R., Lupulescu, M., Şimon, G. and Damian G. (1993) The tellurides of the Romanian Neogene ore deposits. Pp. 73-76 in: Current Research in Geology Applied to Ore Deposits (P. Fenoll Hach Ali, J. Torres-Ruiz and F. Gervilla, editors). University of Granada, Spain.

Cioflica, G., Jude, R., Lupulescu, M., Şimon, G. and Damian, G. (1995) New data on the Bi-minerals from the mineralizations related to Palaeocene magmatites in Romania. Romanian Journal of Mineralogy, 76, 9-23.

Cioflica, G., Jude, R., Berbeleac, I., Lupulescu, M., Costea, D. and Costea, A. (1999) Epithermal gold mineralizations of low-sulfidation type from Baia de Arieş Mine, Southern Apuseni Mountains, Romania. Revue Roumaine de Géologie, 43, 3-18.

Cook, N.J. (1997) Bismuth and bismuth-antimony sulphosalts from Neogene vein mineralisation, Baia Borşa area, Maramureş, Romania. Mineralogical Magazine, 61, 387-409.

Cook, N.J. (1998) Bismuth sulphosalts from hydrothermal vein deposits of Neogene age, N.W. Romania. Mitteilungen der Österreichischen Mineralogischen Gesellschaft, 143, 19-39.

Cook, N.J. and Ciobanu, C.L. (2002) Tellurides: more than mineralogical curiosities, but also markers of $f \mathrm{~S}_{2}-f \mathrm{O}_{2}$ evolution in zoned hydrothermal systems. International Mineralogical Association, $18^{\text {th }}$ 
General Meeting, Programme with Abstracts, Edinburgh, Scotland, p. 283.

Cook, N.J. and Ciobanu, C.L. (2003) Cervelleite, $\mathrm{Ag}_{4} \mathrm{TeS}$, from three localities in Romania, substitution of $\mathrm{Cu}$, and the occurrence of the associated phase, $\mathrm{Ag}_{2} \mathrm{Cu}_{2} \mathrm{TeS}$. Neues Jahrbuch für Mineralogie, Monatshefte, 321-336.

Cook, N.J., Ciobanu, C.L. and Bøe, R. (2001) Tellurides from the Larga hydrothermal system, South Apuseni Mountains, Romania, and their genetic significance. Romanian Journal of Mineral Deposits, 79 (suppl. 2), 47-48.

Cook, N.J., Ciobanu, C.L. and Bogdanov, K. (2002) Trace mineralogy of the Upper Cretaceous banatitic Magmatic and metallogenetic Belt, SE Europe. 11th Quadrennial IAGOD symposium - Geocongress 2002, Windhoek, Namibia, July 2002. CD Volume of extended abstracts. Geological Survey of Namibia.

Damian, F. and Cook, N.J. (1999) Bi-sulphosalts from the cupriferous mineralisations from Nistru, Baia Mare area. Romanian Journal of Mineralogy, 79 (suppl. 1), 27.

Damian, G. and Costin, D. (1999) New data about the bismuth sulphosalts from the hydrothermal mineralisations from Văratec-Băiuț, Baia Mare District. Romanian Journal of Mineralogy, 79 (suppl. 1), 28.

Douglas, N., Mavrogenes, J., Hack, A. and England, R. (2000) The liquid bismuth collector model: an alternative gold deposition mechanism. Geological Society of Australia, AGC Abstract volume, 59, 135.

Drew, L.J. and Berger, B.R. (2001) model of the porphyry copper/polymetallic vein kin-deposit system: Application in the Metaliferi Mountains, Romania. Pp. 519-522 in: Mineral Deposits at the Beginning of the $21^{s t}$ Century (A. Piestrzynski et al., editors). Swets and Zeitlinger Publishers, Lisse, The Netherlands.

Drew, L.J., Berger, B.R., Bawiec, W.J., Sutphin, D.M., Csirik, G., Korpás, L., Vetö-Ákos, É., Ódor, L. and Kiss, J. (1999) Mineral resource assessment of the Mátra and Börszöny-Visegrád Mountains, North Hungary. Geologica Hungarica, 24, 79-96.

Effenberger, H., Paar, W.H., Topa, D., Culetto, F.J. and Giester, G. (1999) Towards the crystal structure of nagyagite, $\left[\mathrm{Pb}(\mathrm{Pb}, \mathrm{Sb}) \mathrm{S}_{2}\right](\mathrm{Au}, \mathrm{Te})$. American Mineralogist, 84, 669-676.

Elliott, R.P. (1965) Constitution of Binary Alloys. $1^{\text {st }}$ Supplement. McGraw-Hill, New York.

Ghiţulescu, T.P. and Socolescu, M. (1941) Étude géologique et minière des Monts Metallilifères (Quadrilatère aurifère et régions environnantes). Anuarul Institutului Geologic al Romaniei, 21, $181-464$.

Ianovici, V., Giuşcă, D., Ghiţulescu, T.P., Borcoş, M., Lupu, M., Bleahu, M. and Savu, H. (1969) Evolutia
Geologică a Muntilor Metaliferi. Editura Academiei Republicii Socialiste România, 741 pp. (in Romanian).

Ioan, M., Şimon, G. and Alderton, D.H.M. (1993) A new occurrence of tellurides at Magura Hondol, Metaliferi Mountains, Romania. Romanian Journal of Mineralogy, 76 (suppl. 1), 25.

Karup-Møller, S. and Makovicky, E. (1979) On pavonite, cupropavonite, benjaminite and oversubstituted gustavite. Buletin de Mineralogie, 102, 351-367.

Kase, K., Kusachi, I. and Kishi, S. (1993) Rucklidgeite solid-solution in the Yanahara deposit, Japan. The Canadian Mineralogist, 31, 99-104.

Koch, S. and Grasselly, G. (1950) Altaite from Stănija (Sztanizsa Roumania). Acta Universitatis Szegediensis. Sectio scientiarum naturalium. (Pars Mineralogica-Petrographica), 4, 47-49 (in Hungarian).

Lupulescu, M. (1997) Nagyagite: New data and considerations. Revue Roumaine de Géologie, 41, $29-36$.

Popescu, G.C. and Constantinescu, E. (1992) First occurrence of coloradoite in Romania. Revue Roumaine de Géologie, 36, 33-34.

Popescu, G.C. and Simon, G. (1992) New tellurides from Săcărìmb, Metaliferi Mountains. Romanian Journal of Mineralogy, 75 (suppl. 1), 37-38.

Popescu, G.C. and Şimon, G.G. (1995) Contributions to the study of tellurides from Săcărîmb (Nagyag), Romania. Romanian Journal of Mineralogy, 76, $37-42$.

Pring, A., Jercher, M. and Makovicky, E. (1999) Disorder and compositional variation in the lillianite homologous series. Mineralogical Magazine, 63, 917-926.

Ramdohr, P. and Udubaşa, G. (1973) Frohbergit Vorkommen in den Golderzlagerstätten von Săcărîmb und Faţa Băii (Rumänien). Mineralium Deposita, 8, 179-182.

Roşu, E. (2001) Neogene magmatism in the Apuseni Mountains, Romania. Evolution and geochemical features. Romanian Journal of Mineral Deposits, 79 (suppl. 2), 19-22.

Shimizu, M. and Shikazono, N. (1985) Iron and zinc partitioning between coexisting stannite and sphalerite: a possible indicator of temperature and sulfur fugacity. Mineralium Deposita, 20, 314-320.

Shimizu, M., Shimizu, M., Cioflica, G., Shimazaki, H., Kovacs, M., Lupulescu, M., Petrusan, G.S., Feigel, M., Popa, G., Refec, I., Pânzan, I. (1999) New informations on opaque minerals from Neogene ore deposits in Romania. International Symposium 'Mineralogy in the System of Earth Sciences', Abstract volume, University of Bucharest, p. 101.

Şimon, S.G. and Alderton, D.H.M. (1995a) Pilsenite, $\mathrm{Bi}_{4} \mathrm{Te}_{3}$ from the Săcărâmb gold-telluride deposit, 
Metaliferi Mts; first occurrence in Romania. Romanian Journal of Mineralogy, 76, 111-113.

Şimon, G. and Alderton, D.H.M. (1995b) Preliminary data for a $(\mathrm{Au}, \mathrm{Ag}) \mathrm{TeO}_{2}$ phase from Săcărîmb goldtelluride deposit; a new mineral species or a mixture? Romanian Journal of Mineralogy, 77 (suppl. 1), 45.

Şimon, G., Alderton, D.H.M. and Bleser, T. (1994) Arsenian nagyagite from Sacarimb, Romania; a possible new mineral species. Mineralogical Magazine, 58, 473-478.

Şimon, G., Alderton, D.H.M., Stumpfl, E.F. and Bleser, T. (1995) Tellurantimony in Romania; first occurrences in Europe. Mineralogy and Petrology, 53, $115-124$.

Stanley, C.J., Roberts, A.C. and Harris, D.C. (1994) New data for nagyagite. Mineralogical Magazine, 58, 479-482.

Tomkins, A.G., and Mavrogenes, J.A. (2001) Redistribution of gold within arsenopyrite and löllingite during pro- and retrograde metamorphism: Application to timing of mineralization. Economic Geology, 96, 525-534.

Udubaşa, G., Istate, G., Dafin, E. and Braun, A. (1976) Mineralizaţiile polimetalice de la Bocşa ( $\mathrm{N}$ de Săcărîmb, Munţii Metaliferi). Dari de seama ale şedinţelor, sect. 2 (Zăcăminte), 62, 97-124 (in Romanian).

Yund, R.A. and Kullerud, G. (1966) Thermal stability of assemblages in the $\mathrm{Cu}-\mathrm{Fe}-\mathrm{S}$ system. Journal of Petrology, 7, 454-488.

Yusa, K., Kitakaze, A. and Sugaki, A. (1979) Synthesized bismuth-tellurium-sulfur system minerals. Science Reports of the Tohoku University, $3^{\text {rd }}$ series, 14, 121-33.

[Manuscript received 15 January 2003:

revised 30 July 2003] 
